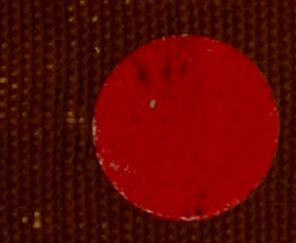




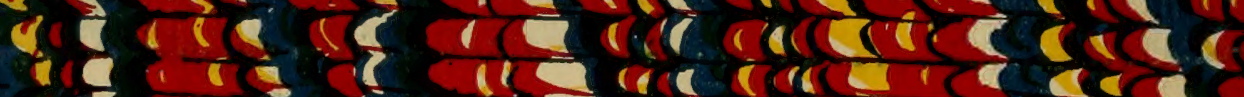

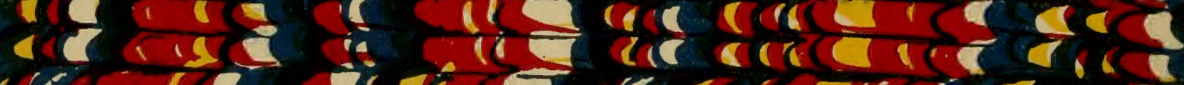

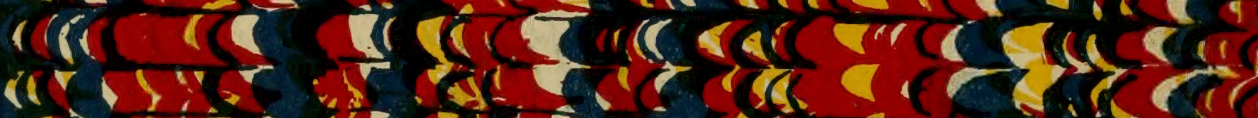

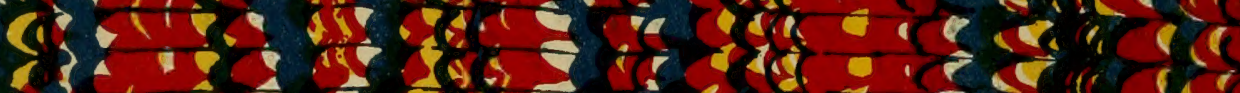

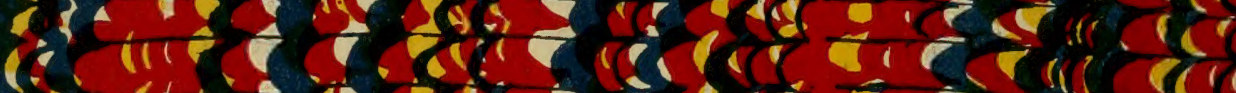

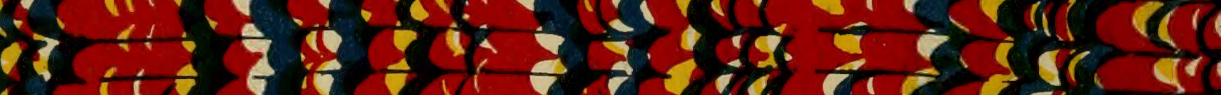

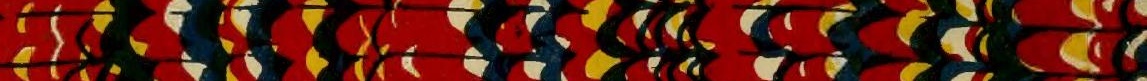

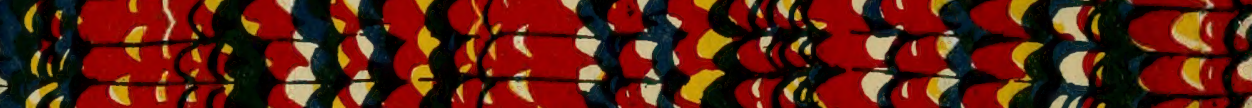

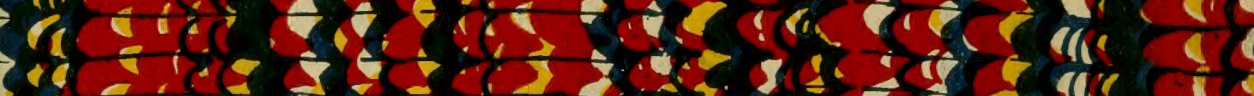

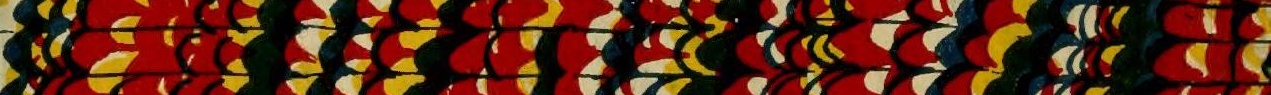

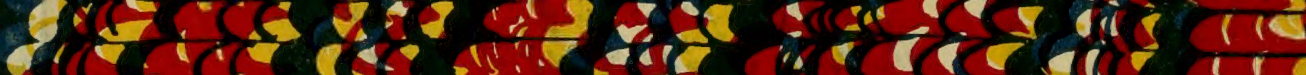

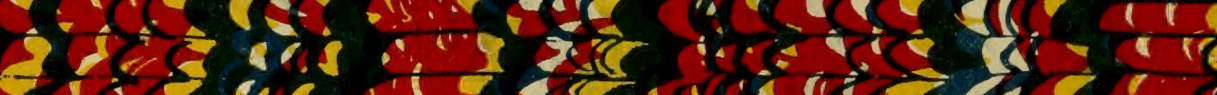

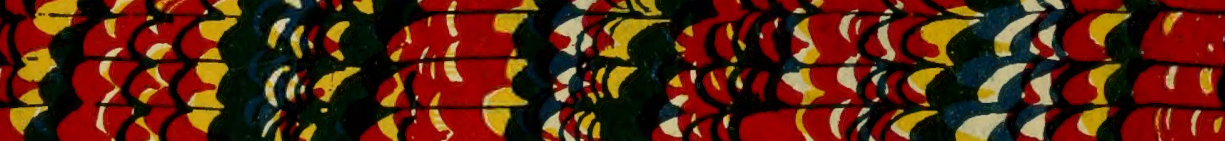

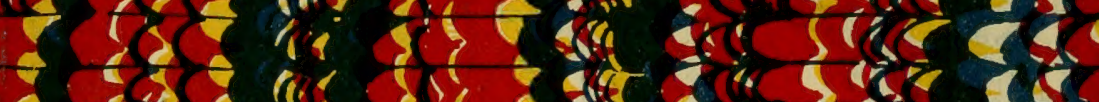

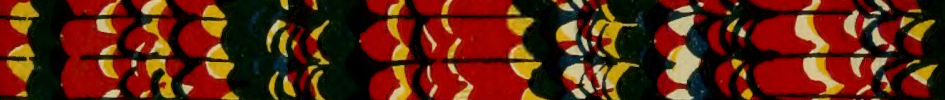

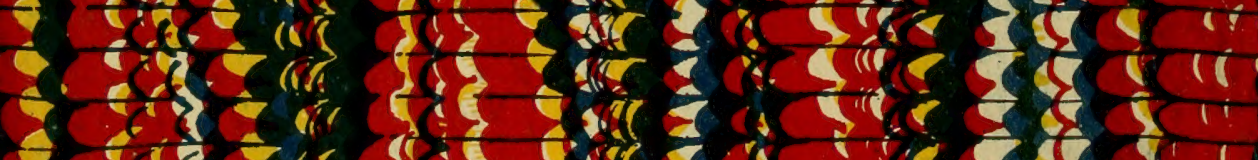

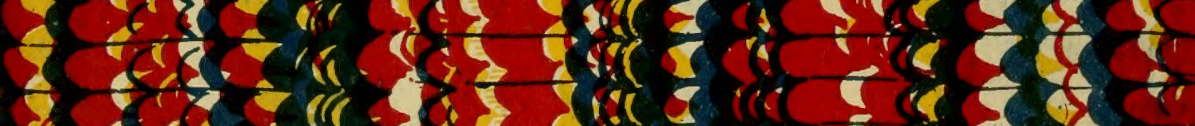
a - sé

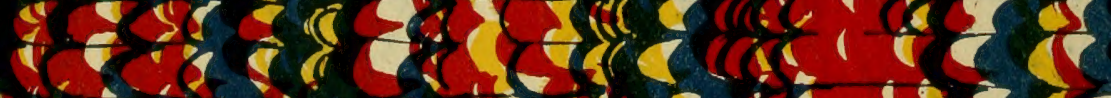

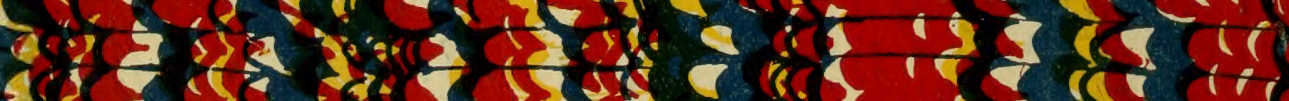

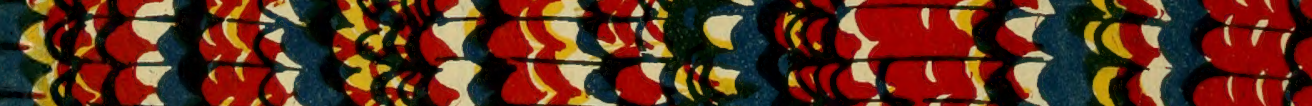

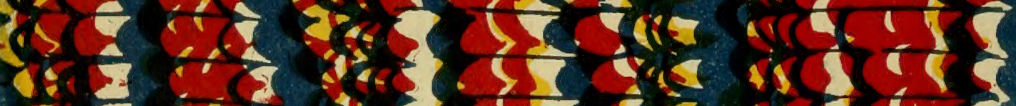

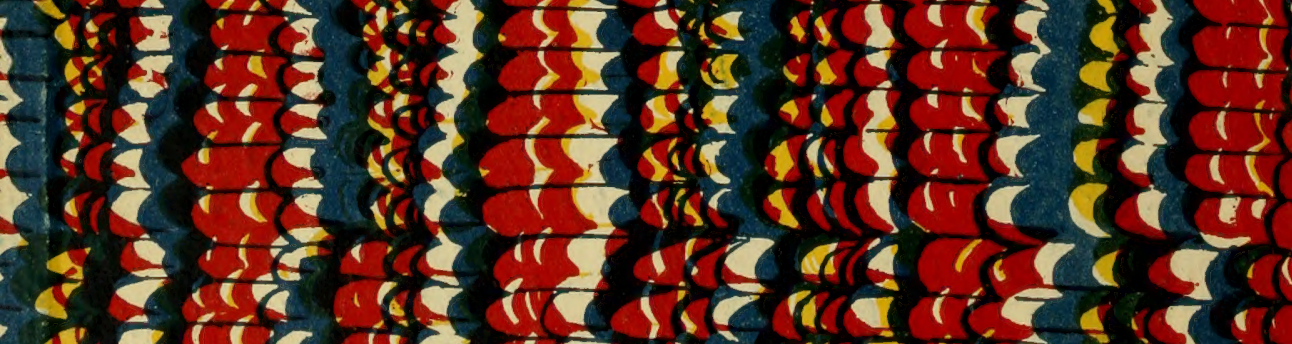

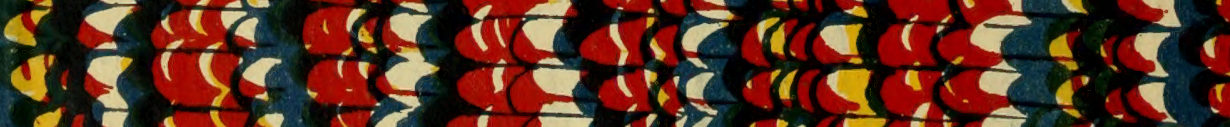

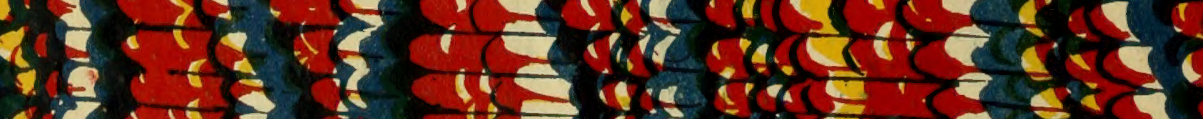

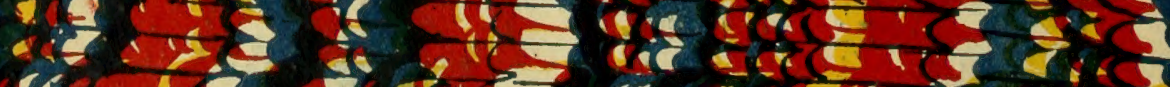

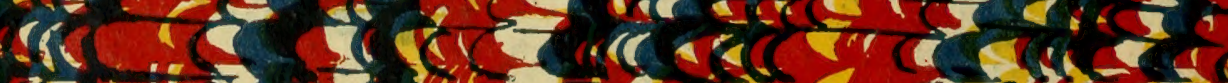

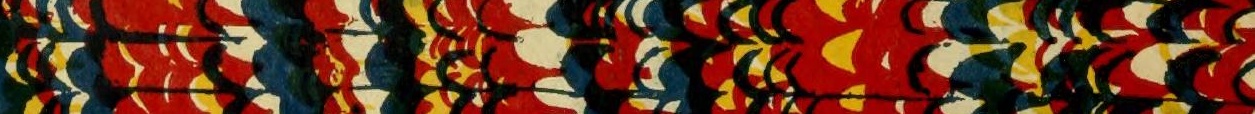

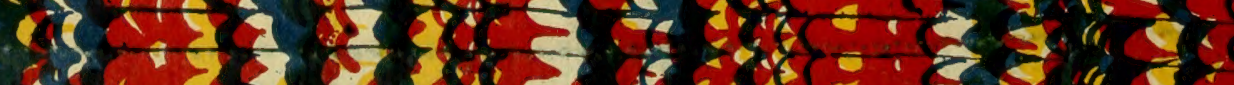


- Ind

$81<16$

Cद

de $\operatorname{cic}(\mathrm{c}) \mathrm{cos}$

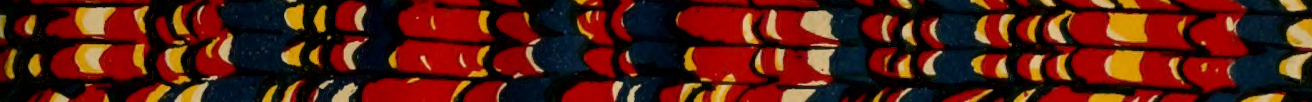
c) $1($ (

is cer rack

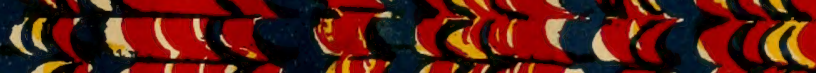

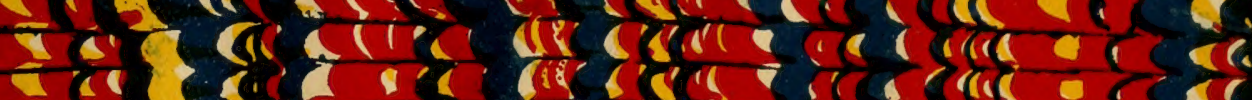

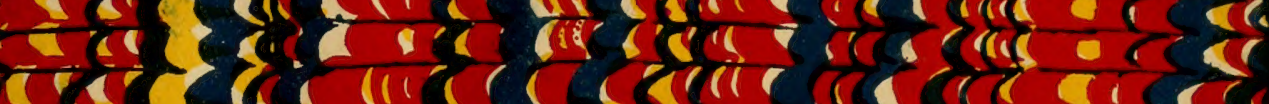

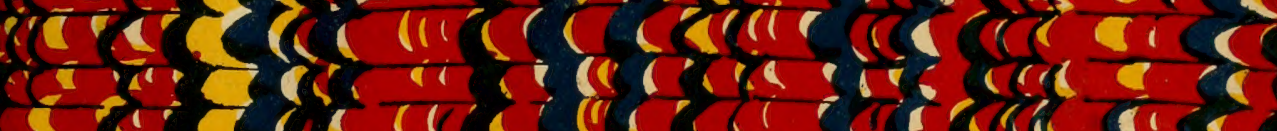

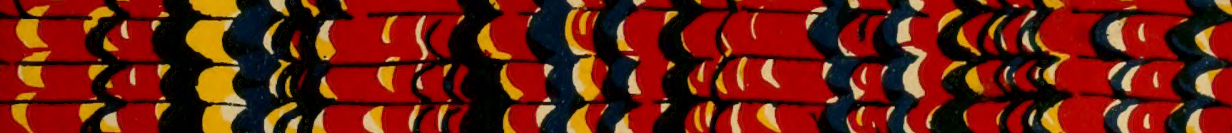

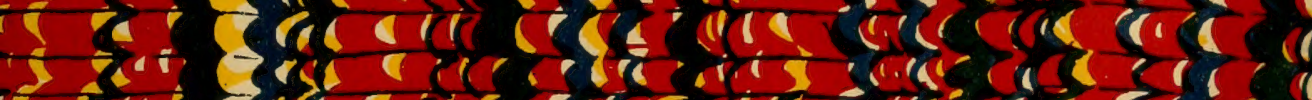

5 all

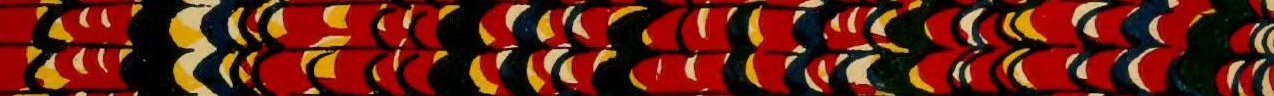

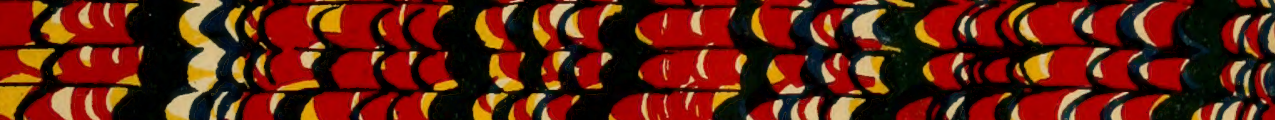

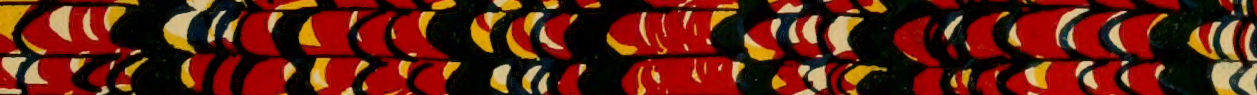

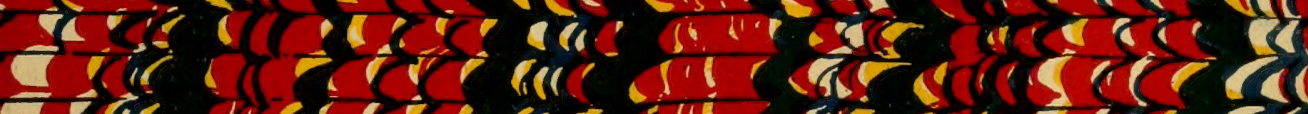

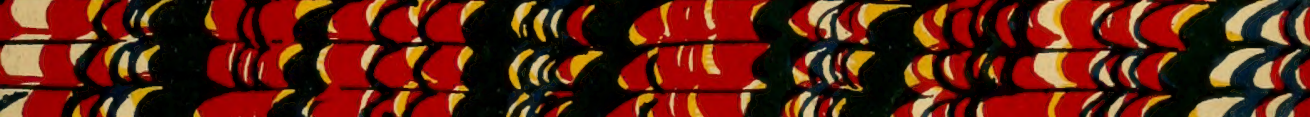

-

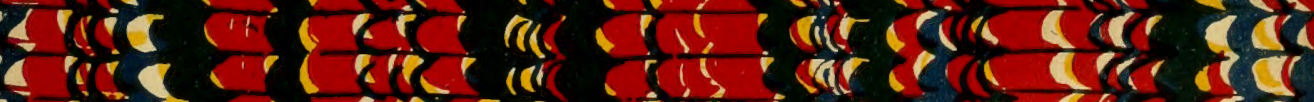

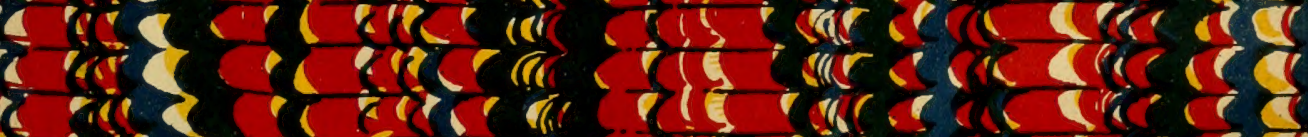

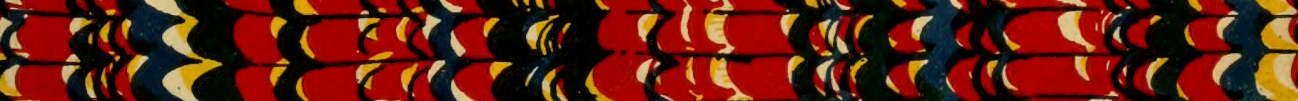

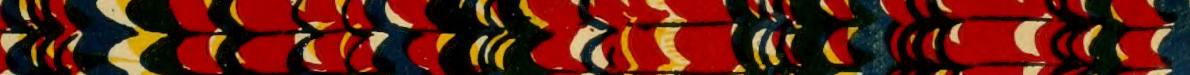

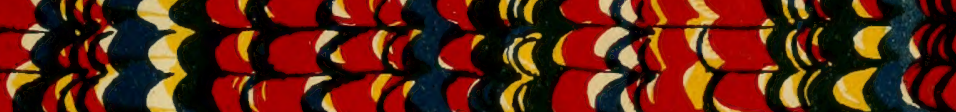

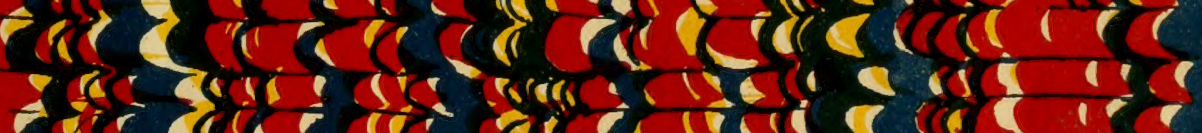

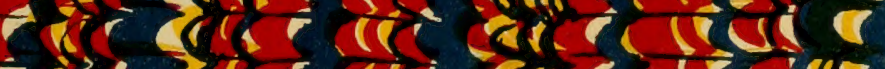

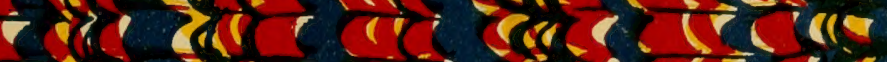

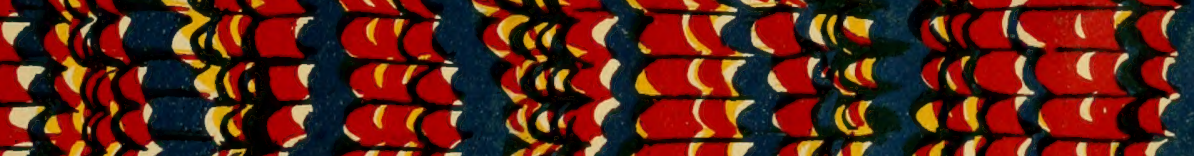

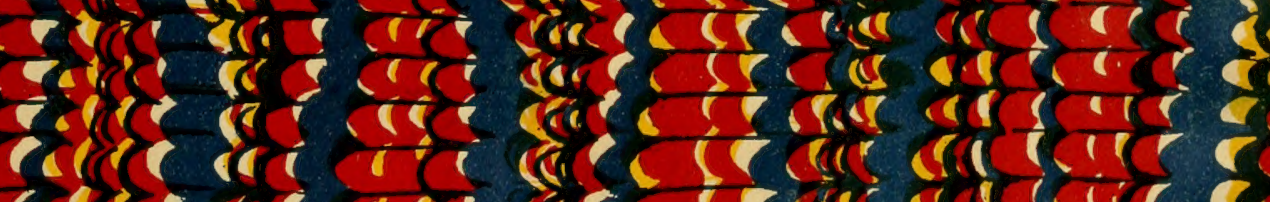

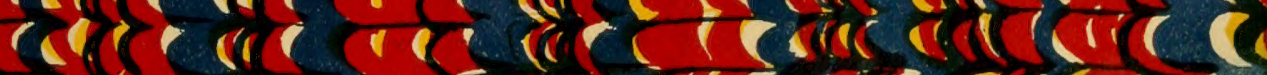

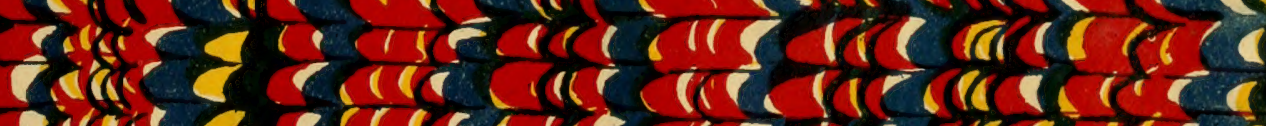

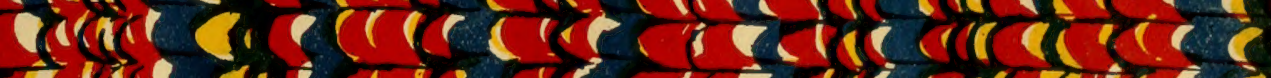

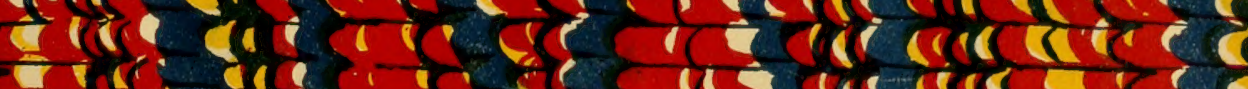

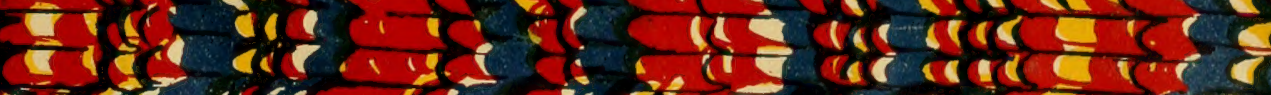

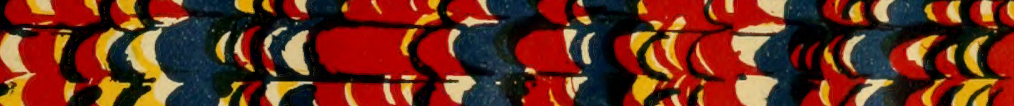
rivitiv an

-1
-1

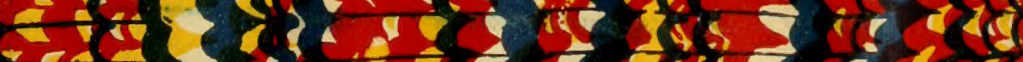







$$
\mathrm{D}_{\mathrm{L}^{2}}
$$



2

64922

J'axon, William

Crayfishes. (Binders title).

$v .2$.

244743 



\section{CONTRIBUTIONS FROM THE}

ZOÖLOGTCAL LABOORATORY OF IIIE MUSEOM OF COMPARATIVE ZOÖLOGY

AT HARVARI) COLLEGE.

\section{DESCRIPTIONS .}

UF

\section{NEW SPECIES OF CAMBARUS;}

TO. WHICH IS ADDED

\section{A. SYNONYMICAL LIST OF THE KNOWN SPECIES OF CAMBARUS AND ASTACUS.}

\section{BY WALTER FAXON.}

[Reprinted from the Proceedings of the AMerican ACademy of Auts and Sclences, Vol, XX.]

DECEMBER, 1884. 



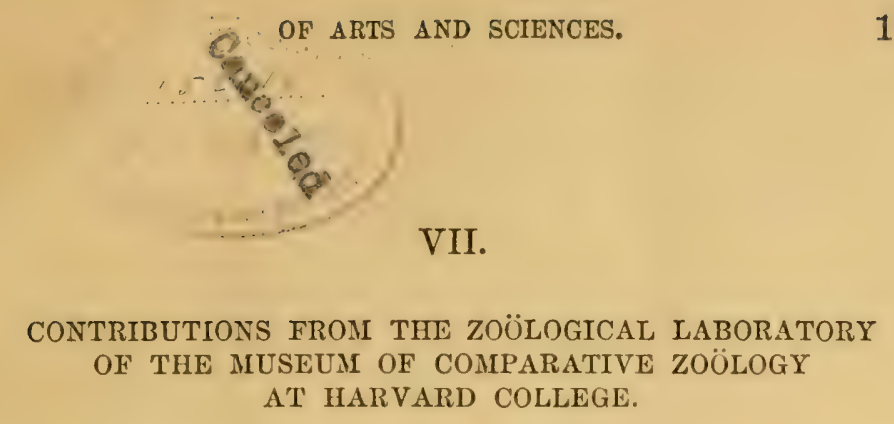

No. VII. - DESCRIPTIONS OF NEW SPECIES OF CANBARUS; TO WHICH IS ADDED A SYNONYMICAL LIST OF THE KNOWN SPECIES OF CAMBARUS AND ASTACUS.

\section{By Walter Faxon.}

\section{Communicated November 12th, 1884.}

Sixteen years have elapsed since the North American Crayfishes were revised by Dr. Hagen.* In the mean while a large amount of new material has accumulated in the Museum of Comparative Zoölogy. On examination, this material revealed so many new forms, and shed so much light on the variability and geographical distribution of these animals, that it seemed desirable to subject the group anew to a critical revision. With this in view I have examined all the collections accessible, including those belonging to the Museum of Comparative Zoölogy, the Boston Society of Natural Inistory, the Peabody Academy of Science at Salem, Mass., the Academy of Natural Sciences of Philadelphia, the United States National Museum at Washington, D. C., Yale College, New Haven, Conn., Bowdoin College, Brunswick, Me., and Butler University, Irvington, Ind., together with the private collections of Mr. P. R. Uhler of Baltimore, Md., Prof. O. P. Hay of Irvington, Ind., Prof. L. A. Lee of Brunswick, MLe, Prof. A. S. Packard of Providence, R. I., Prof. D. S. Jordan of Washington, D. C., Mr. R. S. Tarr of Gloucester, MIass., Dr. C. Hart Merriam of Locust Grove, N. Y., and Prof. B. F. Koons of Mansfield, Conn. Only through the kind offices of the curators of these collections was a thorough revision of this difficult group possible. I hare now ready for the press the first part of a revision of the Astacina, embracing

* Ill. Cat. Mus. Comp. Zoöl., No. III. This monograph was finished in 1868 , although not published until 1870 . 
all the Crayfishes found in the Northern hemisphere, viz. the family Potamobiida of Huxley. Orving to unavoidable delay in the publication of the full Revision in the Memoirs of the Museum of Comparatice Zoölogy, illustrated by quarto lithographic plates, it is thought advisable to publish the following descriptions of the new species. All of them will be figured in the final Memoir.

\section{GeNus CAMBARUS.}

\$1. Third and fourth pairs of legs of male furnished with hooks on the third segment. First abdominal appendages of the male with outer part truncate at the tip and furnished with one to three small recurved teeth, inner part ending in an acute spine which is generally directed outwards.

a. Rostrum with ante-apical lateral spines.

1. C. HAYI, sp. nov.

Male, form I. Rostrum broad, triangular, excavated, sparsely pubescent above, acumen short, lateral spines moderate. Carapace punctate above, gramulated on the sides, the granules ciliate. Lateral spines slightly developed in fully-grown individuals, more prominent in the young. Areola narrow. Abdomen broad, shorter than the cephalo-thorax. Pleural angles rounded. Proximal segment of telson with two spines on each side of the distal border. Hind margin of telson slightly coucave. Anterior process of epistoma broadly triangular. Antennæ shorter than the body. Antennal scale a little shorter than the peduncle, equal to the rostrum, broad, broadest at the middle. Chelipeds slender, chela long, inner and outer margins parallel, squamoso-tuberculate, tubercles ciliate, those along the inner margin of the hand blunt spiniform. Fingers longer than the hand. Opposed margins of fingers ciliate, with one or two small spinous teeth. Carpus long triangular, smooth without, tuberculate and spinous within. Meros with scattered puncta without, tuberculate on the upper margin, one or two spines at the anterior end of upper margin, two rows of spines beneath. Third and fourth pairs of legs hooked on third segments. Anterior abdominal legs of moderate length, deeply excavated on the outer side near the tip. A beardlike tuft of cilia from the protuberance behind the excavation. Tip bears three flattened horny teeth. Inner part ciliate, with a long spine directed outwards and forwards.

'The second form of the male has shorter chelipeds, smaller hooks 
on the second and third pairs of legs, the terminal teeth of the first pair of abdominal legs smaller and not corneous.

In the female the chelipeds are short, the chelæ broad. Sternum bituberculate between the fourth pair of legs. Annulus ventralis umbilicoid, with a tubercle in the median depression.

Length, $100 \mathrm{~mm}$. Rostrum, $15 \mathrm{~mm}$.; acumen, $3 \mathrm{~mm}$. Length of carapace, $51 \mathrm{~mm}$. From cervical groove to posterior margin of carapace, $18.5 \mathrm{~mm}$. Abdomen, $50 \mathrm{~mm}$. Width of areola, $1.5 \mathrm{~mm}$. Chelipeds, $92 \mathrm{~mm}$. Chela, $43 \mathrm{~mm}$.

Known localities. Mississippi: Macon, Artesia.

Closely related to Cambarus Blandingii, but easily distinguished by the first pair of abdominal legs of the male, which are characteristic even in very small specimens. Over a dozen specimens of this species (including males of the first form, males of the second form with first pair of abdominal appendages articulated near the base, and unarticulated, and females) were collected by Prof. O. P. Hay in Eastern Mississippi. One lot has a particular locality specified, Macon. Macon is situated on the Noxubee, an afluent of the Tombigbee River. Another lot was collected at Artesia, a town about twenty miles north of Macon.

\section{C. PUBESCENs, sp. nov.}

Male, form II. Rostrum long, triangular, sides sub-parallel at the base, then converging towards the lateral spines, which are evident; slightly depressed above at the base, subplane, with raised margins; ciliated especially on the acumen; acumen long, pointed. Postorbital ridges with anterior spines. Carapace cylindrical, fore border angulated behind the antennæ, punctate above, slightly granulated on the sides, with one lateral spine on each side. Cerrical groove ciliated. Cardiac region short (much less than one third as long as the anterior part of the carapace). Areola broad. Sternum covered with a dense growth of coarse setr. Abdomen longer than the cephalo-thorax. Proximal segment of telson armed on each side with four spines. Anterior process of epistoma broad triangular with ciliated margin. Basal segment of antennule with a sharp spine below near the inner margin of the middle of its length. Antennx shorter than the body. Second and third segments with acute external spine; scale a little longer than peduncle of antennx and rostrum, moderately broad, broadest below the middle. Third maxillipeds hairy within and below. Chela moderately broad, covered with inconspicuous ciliate squamous tubereles, internal margin nearly straight. 
Fingers as long as the hand, densely ciliated. Carpus tuberculate, a prominent spine within, and one near each point of articulation with the chela. Meros smooth outside and inside, tuberculate and spinous above, biserially spinous and ciliate beneath. Third and fourth pairs of legs toothed on the third segment. Fifth pair of legs with a hook on the basal segment. Anterior abdominal appendages of moderate length, articulated at the base, internal part with an articulated spine obliquely placed, external part terminating in a rounded head with two short, blunt teeth.

Female. Differs from the male in its shorter and smaller claws. The sternum is densely ciliated as in the male. The annulus ventralis conical with sigmoid longitudinal fissure; movable.

Length, $54 \mathrm{~mm}$. Carapace, $26 \mathrm{~mm}$. Abdomen, $29 \mathrm{~mm}$. Distance from tip of rostrum to cervical groove, $19 \mathrm{~mm}$; from cervical groove to posterior border of carapace, $7 \mathrm{~mm}$. Width of areola, $3 \mathrm{~mm}$. Length of chela, $15.5 \mathrm{~mm}$.; breadth, $4 \mathrm{~mm}$. (In the female, which is $59 \mathrm{~mm}$. long, the chela is $12 \mathrm{~mm}$. long by $4 \mathrm{~mm}$. wide.)

Two specimens, one male of the second form and one female, in the U. S. National Museum (No. 3181), collected by A. Graves in IIcBean Creek, a tributary of the Savannah River a little south of Augusta, Georgia, are the types of this species. There are two young female specimens from the same region, Richmond Co., in the Museum of Comparative Zoölogy.

Differs from C. Lecontei and C. angustatus by its broader areola, subplane rostrum, and the pubescence of rostrum and cervical groove. The male appendages also differ, as shown in the description.

b. Rostrum without ante-apical luteral spines (at least in full-grown specimens).

\section{C. Alleni, sp. nov.}

Male, form I. Rostrum broad, triangular, şomewhat deflexed, smooth, excavated above, margins raised into sharp crests and gradually converging to near the tip, where they suddenly approximate each other to form the short, sharp acumen; no lateral spines. Post-orbital ridges without spines. Carapace cylindrical, somewhat compressed laterally, fore border angulated behind the antennx, punctate above, granulated on the sides. Cervical groove deeply sulcated, without lateral spines. Cardiac region more than one third as long as the distance from the tip of rostrum to hind border of carapace. Areola narrow. Abdomen broad, longer than cephalo-thorax. Angles of pleura rounded. Three or four spines on each side of posterior border 
of basal segment of the telson. Terminal segment of telson shorter than basal part, one third broader than long, hind margin concave. Anterior process of epistoma subquadrangular. Basal segment of antennules with a sharp spine below near the inner margin, half-way towards the end of the segment. Antenna shorter than the body, second and third segments with an external sharp tooth. Antennal scale equal to peduncle, slightly surpassing the rostrum, broad, broadest at the middle, rounder at apex, terminating in a short spine, external margin inflated. Third maxillipeds hairy within and below: Chelipeds slenter, chela long, subcylindrical, squamoso-tuberculate. tubercles ciliate anteriorly, internal border straight, serrate. Fingers as long as the hand, with alternate longitudinal ribs and lines of ciliate impressed dots. Opposed margins of finger's straight, unidentate. Carpus squamoso-tuberculate within, obsoletely so without, with one prominent spine on inner border. Meros punctate outside, ciliatotuberculate within and on upper margin, which has two ante-apical spines obliquely placed; two rows of spines bencath. Third and fourth pairs of legs hooked on third segments, hooks of fourth pair bitubereulate. Fifth pair of legs with a flattened laminate tubercle on basal joint. Anterior abdominal appendages of moderate length, bifid at apex, outer part forming a broad flattened plate whose anterior margin is furnished with hairs and one strong seta, the posterior margin of the plate produced anteriorly into a blunt tooth-like process. Inner part bearded within, and produced into a long erect spine, which much exceeds in length the outer part of the appendage.

Length, $62 \mathrm{~mm}$. Rostrum, $6 \mathrm{~mm}$. Carapace, $30 \mathrm{~mm}$. From tip of rostrum to cervical groove, $19.5 \mathrm{~mm}$. From cervical groove to posterior border of carapace, $10.5 \mathrm{~mm}$. Abdomen, $32 \mathrm{~mm}$. Width of areola, $7 \mathrm{~mm}$. Antenux, $47 \mathrm{~mm}$. Chelipeds, $49 \mathrm{~mm}$. Chela, $23 \mathrm{~mm}$. Width of chela, $6 \mathrm{~mm}$.

St. John's River, Hawkinsville, Orange Co, Fla. : J. A. Allen.

A well-marked species with toothless excavated rostrum (younger specimens probably have margiual rostral teeth), narrow areola, long, subcylindrical chelipeds corered with ciliated squamous tubercles. The first ahdominal legs are not jointed, the hooks on the third and fourth pairs of thoracic legs are large and well-finished, so that I consider the single specimen examined to be the first form.

In the collection of the Academy of Natural Sciences of Philadelphia there is a specimen from Hernando Co., Fla., Jos. W. Wilcox, which is probably the second form of the male of this species. 'The sexual appendiges are not articulated at the base. The hooks on the 
third and fourth pairs of legs are small tooth-like processes merely. Besides the differences in these hooks and in the sexual appendiges the following may be pointed out: the rostrum has small lateral teeth near the tip, the post-orbital rilges have a sharp spine at their auterior end, the basal segment of the fifth pair of legs is armed with a sharp hooked tooth in place of a flattened tubercle, and the hind segment of the telson is longer in proportion to its width.

\section{§ 2. Third pair of legs of male hooked. First pair of abdominal appendages of male as in $\S 1$.}

\section{C. smulans, sp. nov.}

Male, form I. Rostrum broad, deeply excavated; margins raised into sharp crests which overhang the base of the sides of the rostrum, converging, sinuated before the tip to form the short acumen; no lateral spines; the acumen is barely margined. Post-orbital ridgres subacute in front, divergent and ending in slight callosities behind. Carapace ovate, narrowing in front, gastric area smooth, cardiac area lightly punctate, sides granulate; anterior border notched behind the antenux; cervical groove sinuate, split on the sides, with a minute terminal branchiostegian spine; vo lateral spine; areola more than one half as long as the distance from the point of the rostrum to cervical groove, narrow, carinate, expanding into an anterior and a posterior triangular field; two longitudinal dotted lines run along the areola from the anterior triangle to the posterior triangle, which is irregularly and sparsely dotted. Abdomen broad, shorter than carapace, punctate, posterior margins of pleura obliquely convex; hind margin of anterior segment of telson bi- to multi-denticulate on each side, posterior segment short, hind border almost straight; median rib of inner plate of swimmeret ends inside of the margiv. Basal segment of antennule with a spine below. Antenna shorter than body, second and third segments furnished with minute blunt spinules, scale a trifle longer than the rostrum, very broad, broadest in the middle, truncate at apex, external terminal spine minute. Anterior process of the epistoma triangular, antero-lateral borders convex, rimmed, anterior angle truncate or notehed in old specimens, with a projecting median spine. Third maxillipeds densely hairy within and beneath. Chela long, slender, squamoso-tuhereulate, internal maryin long, straight, strongly dentate; fingers long, punctate, external border of movable finger tuberculate, inner border of both fingers toothed, a prominent tubercle near the base of exterual finger opposite a more or less clearly marked incision 
in the base of the thumb. Carpus triangular, obliquely truncate, inner margin armed with a stout spine and some low, scattered tubercles, lower side with two or three teeth and numerous small tubercles. Superior margin of meros with short spines, which are sometimes obsolescent except the distal ones; below, the biserial spines are well developed. Sternum hairy. Third pair of legs hooked. First pair of abdominal appendages strong, straight, interual part with a very small, straight apical spine, which does not reach the end of the exterual part; external part with two horny terminal teeth, one of which is flat and disc-shaped, the other slender and somewhat curved.

Length, $97 \mathrm{~mm}$. Breadth, $27 \mathrm{~mm}$. Length of carapace, $51 \mathrm{~mm}$. Length of areola, $18 \mathrm{~mm}$. Width of areola, $1.3 \mathrm{~mm}$. Length of rostrum, $11.5 \mathrm{~mm}$. Length of chela, $50.5 \mathrm{~mm}$.

Male, form II. Chelipeds smaller, hooks on the third pair of legs smaller, first abdominal appendages without horny teeth at apex.

Female. Chelæ sinaller and shorter-fingered than in the male; annulus ventralis bituberculate in front, each tubercle denticulate.

Known localities. Texas: Dallas; east of Canadian River (Coll. U. S. Nat. Mus.). Kansas: Fort Hays.

This species is remarkable in having the general form of body and claw of the $C$. Blandingii group of species, while the fact that only the third pair of legs are hooked places it in the $C$. advena group. The male appendages and the female anuulus are very near to those of $C$. gracilis. In the shape of the body, areola, antemnal scale, and claw, it resembles C. Blandingii, var. acutu, but the rostrum is deeply excarated, and toothless even in small specimens. The full cephalo-thorax and large abdomen seem to indicate that it is not a pre-eminently burrowing species, like its allies, $C$. gracilis, C. advena, \&c.

There are specimens in the United States National Museum collected by the United States Exploring Experlition West of the IIundredth Meridian in pools east of the Camadian River. This locality, I presume, is within the limits of the State of Texas.

\$3. Third pair of legs of male looked. First pair of abdominal appendages of male thick, terminating in two short, recurved teeth.

a. Rostrum devoid of lateral teeth.

5. C. ncuminatus, sp. nov.

Rostrum long, tapering, ending in a long, sharp acumen, without lateral spines; upper surfice smooth, somewhat hollowed out, margins punctate, ciliate, raised into low sharp crests. P'ust-orbital ridges with vol. $\mathbf{x x}$. (N. S. XIr.) 
sharp aisterior spines. Carapace smooth, punctate, granulated on the sides, cervical groove sulcate, sinuate; a sharp lateral and branchiostegian spine; sub-orbital angle rounded; an irregular indentation on the side of the carapace, below the lateral spine, on the hepatic region and anterior part of the branchial region; areola broad, smooth, punctate, less than one half as long as the distance from the tip of the rostrum to the cervical groove. Telson bispinose on each side. Epistoma triangular, augles rounded. Second and third segment of the antenna with a strong sharp spine; scale of moderate length, rather broad, inner margin rounded, outer margin thick, turned outwards at the tip. Third maxillipeds hairy within. Chela moderate, punctate, serrato-tuberculate on internal border, fingers setose on their inner margins, external border of outer finger submarginate. Carpus armed with a strong internal spine and smaller inferior median and external spines. Meros with well-developed biserial spines below and two obliquely placed near the distal end of the superior border. In some specimens one of the superior pair is obsolete. Third pair of legs hookerl. First pair of abdominal appendiges as in C. Burtonii.

Length, $48 \mathrm{~mm}$. Carapace, $23 \mathrm{~mm}$. Rostrum, $6 \mathrm{~mm}$. Areola, $7 \mathrm{~mm}$. Breadth of areola, $2 \mathrm{~mm}$.

Saluda River, west of Greenville, S. C. Collected by Prof. D. S. Jordan. Three specimens, one male of the second form, two females. For the opportunity to examine these I am indebted to Prof. O. P. Hay of Butler University, Irvington, Ind. Differs from the other species of the $C$. Bartonii group by its long, gradually tapering rostrum, short metacarapace, strongly developed spines of carapace, antennie, and meros. The acumen of the rostrum is scarcely upturned at the tip.

Specimens from North Carolina, Old Fort, MIcDowell Co., and French Broar River, (in Mus. Comp. Zoül. and Acad. Nat. Sci. Phila.), differ from the above in having the rostrum flitter and less atteuuated at the tip, a shorter antennal scale, sub-orbital angle produced into a sharp spine. These may prove to be a distinct species from the Saluda River specimens. They approach $C$. robustus, but may be distinguished from that species by the longer-pointed rostrum, shorter metacarapace, better-developed spines, etc.

\section{C. DuBius, sp. nov.}

Rostrum short, broad, sides sub-parallel from the base to near the tip, when they suddenly converge to form the short, broadly triangular acumen; the rostrum is angulated but not toothed at the base of the 
acumen; upper surface of rostrum concare, sides thickened, punctatelined. Post-orbital ridges without spines, slightly swollen at the posterior end. Carapace longer than the abdomen, oval, punctate, gramulated on sides, posterior dorsal maryin depressed, cervical groove hardly sinuate, crossing the median line of the back half-way between the base of the rostrum and the posterior margin of the carapace; lateral and branchiostegian spines obsolete; sub-orbital angle little developed, obtuse; areola narrow, with two irregular longitudinal rows of dots. Epistoma subquadrangular. Abdomen small, short; anterior segment of telson bispinose on each side, posterior segment rounded behind. Antennæ shorter than the body, second and third segments without spines, scale small. External maxillipeds hairy within. Chela punctate, inner margin of hand serrato-tuberculate, outer margin thickened, serrate; fingers somewhat down-curved, slightly gaping, toothed on their opposed margins. Carpus with a strong tooth on the inner side, teeth of the lower side obsolescent. Superior border of meros serrate, lower side armed with two rows of spines. Third pair of legs hooked. First pair of abdominal legs of the first form of the male short, thick, twisted, internal part cylindrical, recurver, with pointed apex; external part broader, plane within, apex recurved, compressed, external margin corneous, striated.

Leugth, $62 \mathrm{~mm}$. Length of carapace, $33.5 \mathrm{~mm}$. Length of abdomen, $28.5 \mathrm{~mm}$. Length of rostrum, $5 \mathrm{~mm}$. Metacarapace, $15 \mathrm{~mm}$. Width of areola, $1.5 \mathrm{~mm}$.

Known localities. West Virginia: Cranberry Summit, Preston Co. Virginia: P'ennington's Gap, Lee Co. Tennessee: Cumberlaud Gap.

This species has the general appearance of $C$. Diogenes, but the rostrum is short, as in $C$. Bartonii, and the areola is not obliterated in the middle by the apposition of the branchio-cardiac lines. The fer (four) specimens which I have seen come from the Appalachian Mountain region of Virginia and West Virginia. According to Mr. Uhler, it makes mud chimneys like $C$. Diogenes, which it seems to represent in the mountain regions, $C$. Diogenes belonging to the lowlands.

\section{C. Argillicola, sp. nov.}

Rostrum short, broad, down-curved, excavated, with a deep foveola at base; acumen short, broadly triangular, acute, no lateral spines. Post-orbital rirlges without anterior spines, swollen behind. Cephalothorax laterally compresserl, carapace punctate, anterior border not angulated, cervical gronve sinuate, no lateral or branchiostegian spitse. 
Areola linear in the middle, with an anterior and posterior triangular space, the latter the larger. Abdomen broad, but narrow at the base, longer than the cephalo-thorax. 'Telson uni- or bi-spinose on each side. Epistoma rounded in front. Antennal scale small, rounded within. Third maxillipeds heavily bearded within, lightly so beneath. Chela large, hand swollen, denticulate on inner border, irregularly punctate, fingers flattened laterally, punctate and costate; the movable finger has a single row of tubercles on external border and a very prominent rib on its upper face, its internal, cutting edge is toothed and excised at the base. The outer finger is sharply marginate on its external border, inner border toother and heavily bearded at the base. Carpus armed with a sharp spine and a few minute tubercles within; beneath them is a sharp median anterior spine, and a minute spiniform tubercle between this and the spine of the interual border. Meros furnished with one or two small sub-apical teeth on the superior border, and two rows of teeth below. Second pair of legs ciliate near the end. Third pair of legs of male hooked. First abdominal appendages of male and annulus of female as in C. Diogenes.

Length, $76 \mathrm{~mm}$.

Known localities. Dominion of Canada: Toronto, Prov. Ontario. Michigan: Detroit, East Saginaw (Coll. Peabody Mus. Yale Coll.). Indiana: New Albany. Louisiana: New Orleans (Coll. U. S. Nat. Mus.). North Carolina: Kinston.

Closely related to $C$. Diogenes, but at once distinguished by the sharply compressed fingers bearded at the base, excised thumb with a single row of tubercles on external margin, non-ąngulated anterior border of carapace, etc. The types of this species were dug out of burrows in solid blue clay in Detroit, Mich., by Mr. H. G. Hubbard, in August, 1873. The burrows were three to five feet deep. At the bottom of each burrow was a pocket in a layer of loose gravel and clay, holding water. Just above the water-line an enlargement in the burrow formed a shelf on which the animal rested.

Specimens from Kinston; N. C., and New Orleans, La., which I have referred to this species, are not adult, and cannot be determined with absolute certainty.

\section{C. Uhleri, sp. nov.}

Male, form I. Rostrum of moderate length, sides nearly parallel to base of acumen, which is broadly triangular, acute; no lateral spines; upper surface of rostrum plane, punctate, lightly foveolate at base, margins raised into a low, sharp crest, punctate-lineate; there is 
a faint trace of a median longitudinal carina. Post-orbital ridges without anterior spines, swollen posteriorly. Carapace oval, punctate, granular on sides. Antero-lateral border not angulate or notched. No lateral or branchiostegian spines. Cervical groove sub-sinuate. Areola none. Abdomen longer than cephalo-thorax. Anterior segment of telson bispinose on each side, posterior segment round behind. Epistoma triangular. Antenne short, with very small spines on the second and third segments, seale short, broad, inner margin rounded. Third maxillipeds hairy within and beneath. Chela moderate, hand inflated, punctate, ciliate, inner margin ornamented with a row of sharp dentiform tubercles, outside of which is a row of smaller tubercles. Fingers compressed, punctate and costate, movable finger with a single row of tubercles on the outer edge, a prominent rib running along the middle of the upper surface, inner margin excised at base and furnished with tuberculiform teeth. External finger toothed within, hairy at base, outer border marginate. Carpus armed with a strong tooth and a ferw small scattered tubercles on the inner side, a stout median anterior spine beneath, and two or three smaller ones between the median and internal spine. Superior border of meros serrate, inferior surface with two longitudinal rows of spines. Second pair of legs densely ciliate on the inner side near the tip. Third pair of legs hooked. First pair of abdominal appendages of male and annulus of female as in C. Diogenes.

Length, $65 \mathrm{~mm}$. Carapace, $30.5 \mathrm{~mm}$. Rostrum, $6.5 \mathrm{~mm}$.

Known localities. Maryland: Carolina Co. (Coll. P. R. Uhler); Dorchester Co.; Talbot Co. (Coll. P. R. Uhler); St. Mary's Co. (Coll. P. R. Uhler); Wicomico Co. (Coll. P. R. Uhler); Somerset Co.; Worcester Co.

This species was discovered by Mr. P. R. Uhler, of Baltimore, in the counties of Maryland enumerated above, on the Chesapeake and Atlantic coasts of Maryland. It is found in salt marshes, covered twice daily by the tides, and also in brackish and fresh-water ditches in company with $C$. Blandingii. In Dorchester County it is found fiur back in the loivlands in the neighborhood of Vienna.

C. Uhleri is easily distinguished from C. Diogenes aud C. argillicola by its plane rostrum, shape of the hand, etc.

\section{b. Rostrum with small lateral lecth. \\ 9. C. Girardianus, sp. nov.}

Male, form II. Rostrum broad, excavated, margins with a line of punct:a, slightly convergent; acumen long, ending in a brown corneons 
upturned tip; a pair of minute, brown horny teeth at base of the acumen. Post-orbital ridges depressed, with sharp anterior spines. Cephalo-thorix as long as the abdomen. Carapace flattened above, densely and finely punctate, slightly granulated and finely ciliated on the branchial and hepatic regions. Cervical groove sulcate, sinuate, with minute lateral spine and terminating with a small brauchiostegian spine; external angle of the orbit very prominent, ending in a spinule. Areola long and wide, plane, punctate, in length more than one half the distance between the tip of rostrum and posterior margin of the carapace; sides nearly parallel to within a short distance of the posterior margin, where they diverge. 'Telson bispinous on each side. Anterior process of epistoma broad. Antenua longer than the body, scale moderately broad, ending in loug, acute apical spine. Third pair of maxillipeds hairy within. Chelipeds moderate; chela large, densely punctate, inner margin short, lightly serrate; fingers long, with parallel rows of puncta, toothed within, onter one bearded within at base. Carpus broad, obliquely truncated, punctate above, with a strong median spine on the inner side and a small double one at the base; below the carpus is armed with a spine on the anterior border. Meros smooth, with a single ante-apical spine on the upper edge and the usual biserial ones beneath; of the latter, only two or three at the proximal end are developed. Thoracic stema naked. Third pair of legs hooked on the third segment. Fourth pair of legs with a small ovate basal tubercle. First pair of abdominal appendages articulated near the proximal end, stout, short, swollen in the middle. External part with the compressed apex in the form of a strong, obtuse, recurved tooth, double within; internal part recurved, cylindrical, short, acute.

Female. Annulus ventralis trausverse, with a sigmoid sulcus.

Measurements of an individual :-

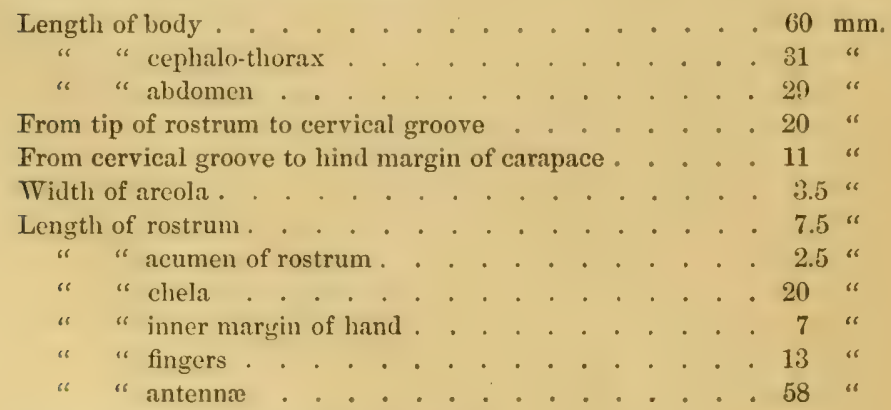

Cyprus Creek, Lauderdale Co., Ala. 
This species is near $C$. extraneus, but differs in its longer and narrower areola, in the short hand and long fingers, the single superior ante-apical spine on the meros, uaked thoracic sterna (in $C$. extraneus they are setiferous), the greater smoothness of the body altogether, and the fineness of the punctation of the carapace; the sub-orbital angle is very much more projecting than in $C$. extraneus.

This species was discovered by Mr. C. L. Herrick in Cyprus Creek, Lauderdale Co., Ala., when collecting under the auspices of the U. S. National Museum, in October, 1882. The specimens obtained were two males, form II., and three females.

\section{C. Jordani, sp. nov.}

Male, form II. Rostrum broad, subplane, sides nearly parallel, acumen long, with minute lateral teeth at base. Post-orbital ridges provided with sharp anterior spines. Carapace punctate (sparsely so on the gastric region), slightly granulated on the sides. $\Lambda$ single acute spine on each side of the carapace behind the cervical groove, and a branchiostegian spine on the anterior border. Sub-orbital angle prominent. Areola long, narrow, widening gradually anteriorly, suddenly posteriorly, smooth, with but few puncta irregularly disposed in its field. Abdomen longer than the cephalo-thorax; proximal segment of the telson bispinous, distal segment rounded posteriorly. Epistoma triangular. Antenna equal in length to the body minus the telson, scale broad, greatest width toward the distal end, which is subtruncate and furnished with a sharp external spine. Third pair of maxillipeds hairy within. Chela punctate, ciliate; inner margin of hand short, serrate ; fingers long, costate, outer border of movable one serrato-tuberculate. Carpus with a strong, acute, median spine, and a small basal spine on inver border; a small spine at each articulation with the chela. Meros smooth on the external surface, two ante-apical spines obliquely placed on the upper edge. First pair of abdominal appendages short, thick, articulated near the base, terminating in tro blunt, recurved teeth.

Length of body . . . . . . . . . . . . . . $47 \mathrm{~mm}$.

" " carapace
"
" "

Length of antenna . . . . . . . . . . 41 " 
Of this species I have seen but one specimen, a male of the second form, collected by Prof. D. S. Jordan in the Etowah River near Rome, Georgia, communicated by Mr. P. R. Uhler of Baltimore. It has a toothed rostrum and first abdominal appendages like $C$. Bartonii. It is distinguished from the other allied species by its flat rostrum and narrow areola.

\section{C. connutus, sp. nov.}

Male, form I. Rostrum long, narrow, excavated above ; margins divergent at the base, thickened, concave, costate; acumen long, with upturned horuy tip; lateral teeth at base of acumen upright, stout, blunt, horny. Post-orbital ridges sulcate on the outer side, with well-developed horny-tipped anterior spines. Carapace flat, smooth, and punctate above, granulated on the sides; a depression on each side just outside the orbital ridges; no sub-orbital angle nor spine; cervical groove sulcated, sinuate, with a strong, sharp lateral spine; no branchiostegal spine; areola long, of moderate width, plane, punctate, widening at the posterior end of the carapace. 'The length of the areola is equal to the distance from the cervical groove to the base of the rostrum. Abdomen broad, as long as the cephalo-thorax without the acumen of the rostrum, pleura triangular, with sharp lateral angles. Terminal segment of telson broader than long, posterior border rounded; anterior segment of telson bispinous on each side. Anterior process of epistoma very broad, short, triangular; apex not truncated nor notched. Thoracic sterna ciliated. Basal segment of antenuule with a spine on lower side on the distal half of the segment. Antenna longer than the body, flagellum very large, composed of annulations flattened in the vertical direction, conspicuonsly bearded along the inner margin. Antennal scale oblique to the horizontal plane of the body, a little longer than the rostrum, inner margin straight and parallel with the outer margin, sub-truncate at the tip, apical spine strong, long and acute; second segment of antenna with a large external spine at base of the scale; another small but well-formed external spine on the following segment below. Chelipeds large. Chela of moderate size; hand smooth, punctate, internal margin serrate; fingers of moderate length, curved slightly downwards, ribbed and punctate above, tips incurvel, horny; external finger serrate on outer margin, impressed above and below at base; inner borders of fingers tuberculate and ciliated especially at their bases. Carpus smooth, lightly punctate above, with a strong median internal spine and a small basal internal spine; a sharp, prominent median anterior spine beneath. Meros smooth, a 
single acute ante-apical spine on the superior margin, ouly one or two distal spines in the outer row of biserial spines beneath. Third joint of third pair of legs hooked. Fourth pair of legs with a conical tubercle on the first segment. First pair of abdominal appendages short, stout, twisted, distal half bent in towards the median line of the body; internal part truncate at apex, with a small spine directed backward and outward; external part longer, ending in a short, recurved, bluut, laterally compressed, horny tooth.

Measurements :-

\begin{tabular}{|c|c|c|c|c|c|c|c|c|c|c|c|c|c|c|}
\hline ngth of body & & & & & & & & & & & & & 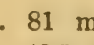 & \\
\hline " cephalo-thorax & & & & & & & - & & & & • & & . 43.5 & \\
\hline "abdomen & & & & & & & & & & & & & . 37.5 & \\
\hline Length from tip of rostrum & to & cer & rvic & cal & gr & OOV & re & & & & & & .27 & \\
\hline From cervical groove to pos & ster & rior & bo & & ler & of & car & rape & ace & & 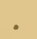 & & 16 & \\
\hline Length of rostrum & & & & & & . & . & . & . & . & . & & 11 & \\
\hline " acumen of rostru & & & & & & & & & & & & & 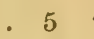 & \\
\hline Width of base of acumen of & ro & & & & & & & & & & & & 3 & \\
\hline " areola & 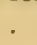 & & . & & • & • & & • & & 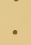 & $\cdot$ & & 3 & \\
\hline Length of antennæ. . & . & . & . & • & ‘ & • & • & . & • & ${ }^{\circ}$ & & & 1 & \\
\hline " " chela. & . & & & & & & & & & . & & & & \\
\hline Width of cliela. . & . & & & & & - & & & & . & & & 5 & \\
\hline Length of movable finger & . & & & & & & & & & & & & & \\
\hline
\end{tabular}

One specimen, collected by Mr. F. W. Putnam in Green River near the Mammoth Cave, Kentucky, November 3, 1874.

This species is very distinct from every other known Crayfish. In its general appearance it approaches those species included in the group typified by $C$. Bartonii. The rostrum, however, is more after the fashiou of $C$.rusticus, but the lateral spines are much larger and stand erect. The impressed external finger recalls $C$. robustus. The sexual appendages are formed nearly as in C. Bartonii. The development of the antennæ is extraordinary.

\section{\$ 4. Third pair of legs of male hooked. First pair of abdominal appendages of male terminating in two elongated, straight tips.}

\section{a. Rostrum without lateral teeth.}

\section{C. MEDIUS, sp. nov.}

Male, form I. Rostrum of morlerate length, excavated, slightly carinated at the tip; margins thickened, converging, sinuated near the tip to form the short triangular acumen; no lateral spines. Post-orbital ridges depressed, sulcated on external face, subacute anteriorly. Cara- 
pace subcylindrical, somewhat flattened above, punctate, granulated on the sides; cervical groove sinuate, no lateral nor branchiostegian spine; sub-orbital angle rounded; areola long (much more than one half as long as the distance from the cervical groove to the tip of the rostrum), of moderate width, punctate, widening posteriorly. Abdomen as long as the cephalo-thorax; telson rounded behind, basal segment bispinous on each side of the posterior border. Basal segment of antenuule with an interior median spine. Second and third segments of antennæ not spiniferous (flagellum of antennx brokeu off in the specimen examined, probably much shorter than the body). Antennal scale short, of moderate width, terminating in a short, acute spine. Anterior process of epistoma triangular, apex pointed, sides convex. Third maxillipeds bearded withn. Chelipeds of moderate length, stout; chela broad, inflated, coarsely punctate above and below, external margin rounded; internal margin of hand with a double row of obsolescent tubercles; fingers stout, gaping at base, costate, heavily dotted-lined, internal margins furnished with rounded tubercles. Carpus sparsely punctate, armed with a moderate median and a smaller basal internal spine; below, there are no spines developed. Meros furnished with two nearly obsolete obliquely-placed tubercles near the distal extremity of superior border, and with a double row of tubercles below. Second pair of legs provided with long cilia towards their distal extremity. 'Third segment of third pair of legs hooked. First pair of abdominal legs long (reaching to base of chelipeds), deeply bifid, rami slender, straight, the outer one a little recurved at the tip, aciculate, the inner one slightly dilated near the tip, blunt pointed; a projecting angle or shoulder at base of rami on anterior margin.

Female. Hand small, fingers not gaping, ciliated within; sternum between fourth pair of legs plane; annulus ventralis bilaterally symmetrical, anterior border bituberculate, posterior border unituberculate, transverse fossa deep, recurved at each end.

Measurements of male, form I. : - Length of body, $49 \mathrm{~mm}$. Length of carapace, $25 \mathrm{~mm}$. Length of rostrum, $6 \mathrm{~mm}$. Length from end of rostrum to cervical groove, $15.5 \mathrm{~mm}$. Length from cervical groove to hind border of carapace, $9.5 \mathrm{~mm}$. Width of areola, $2 \mathrm{~mm}$. Length of abdomen, $25 \mathrm{~mm}$. Length of chela, $23.5 \mathrm{~mm}$. Length of internal margin of hand, $9.5 \mathrm{~mm}$. Breadth of chela, $11.5 \mathrm{~mm}$. Length of movable finger, $14 \mathrm{~mm}$.

Two specimens, first form of male and female, in the Museum of Comparative Zoölogy, from Irondale, Mo.

This species has the general form of body, rostrum, and chelæ of 
the $C$. Bartunii group, together with the male abdominal appendages of the $C$. affinis group. 'These appendiges have a projecting shoulder' at the base of the rami, on the anterior edge, as in C.rusticus, C. Putnami, etc. $C$. immunis and $C$. Mississippiensis, belonging to the C. affinis group, also have the rostrum devoid of lateral spines, but in general habit of body they do not resemble $C$. Bartonii and its allies, as is the case with the present species.

\section{C. Mississippiensis, sp. nov.}

Male, form I. Rostrum broad, twice as long as broad, sub-excavated above, smooth, foveolate at base, margins raised, converging anteriorly, sinuate at apex; acumen short, triangular, acute, no lateral teeth. Post-orbital ridges sulcate on outer side, with short, blunt anterior spines. Carapace densely punctate, sides lightly grinulate, front lateral border not angulated. Cervical groove sinuate, with small lateral and branchiostegian spines. Areoli linear anteriorly to the middle, with a small anterior and a larger posterior, triangular field. Length of areola equal to half the distance from tip of rostrum to cervical groove. Abdomen as long as the carapace. Terminal segment of the telson shorter than the basal segment, hind border slightly concave at the centre; basal segment bispinose on each sicle. Anterior angle of epistoma notched. Sternum between the legs densely ciliated. Antennal scale very broad, apical spine short. Third maxillipeds hairy without and beneath. Chela large, punctate, smooth below, margined without; inner margin of hand short, furnished with dentiform tubercles irregularly disposed in a double series; a little distance from these is another line of smaller ciliated tubercles on the upper surfice of the hand on a line with the middle of the base of the movable finger. Fingers long, gaping at base, each with a punctate impressed line parallel with inner margin, and furnished with rounded tubercles on inner margin. Movable finger tuberculate on outer margin. Outer finger bearded below at base. Carpus broad, obliquely truncate on the external side, punctate and tuberculate above, a strong median internal spine, two small spines near on the base and one at the anterior end near the articulation; multispinous beneath, the two anterior spines the largest. Meros smooth, two ante-apical spines obliquely placed on upper margin, lower face with blunt biserial spines. Second pair of legs with long seta near the end on inner side, not tufted as in $C$. immunis. Third pair of legs hooked. First pitir of abdomiual appendages long, deeply bifil, rami recurved at tip, parallel, internal ramus sub-eylindrical, dilated and grooved at tip, 
external ramus a little longer than the internal, laterally flattened, ending in a slender, sharp point.

Male, form II. Rostrum with small lateral teeth; hand smaller, with smaller tubercles; hooks on third legs smaller; third pair of abdominal appendages stouter, cleft for only a short distance from the tip, tips blunt, no articulation at the base in the one specimen examined.

Female. Rostrum as in the second form of the male. Hand shorter and broader, annulus ventralis with a very deeply excavated fossa.

Measurements of male, form I.:- Length, $73 \mathrm{~mm}$. Length of rostrum, $9 \mathrm{~mm}$. Breadth of rostrum at base, $5 \mathrm{~mm}$. Length of areola, $11 \mathrm{~mm}$. From tip of rostrum to cervical groove, $25 \mathrm{~mm}$. Length of chela, $35 \mathrm{~mm}$. Breadth of chela, $14 \mathrm{~mm}$. Length of inner finger, $24 \mathrm{~mm}$. I Length of internal margin of hand, $11 \mathrm{~mm}$.

Five specimens, one male, form I., one male, form II., and three females, were collected by Prof. O. P. Inay in Eastern Mississippi. Two of them are labelled "Macon, Miss."

Differs from $C$. immunis in its linear areola, flatter rostrum, differently shaped chela, and male appendages, the rami of which are longer and less strongly recurved. C. Palmeri differs from it in its quadrangular rostrum, which has a longer acumen and more prominent lateral spines, narrower and long-spined antennal scale, longer areola; the rami of the male appendages (form II.) are a little longer and more widely separated. C. Alabamensis differs by its wide areola, toothed and carinated rostrum, etc.; C. compressus, by its laterally compressed carapace, wide areola, narrow carinated rostrum, etc.

\section{b. Rostrum with lateral teeth.}

\section{C. Palmeri, sp. nov.}

Male, form II. Rostrum broad, sub-excavated, margins nearly parallel from base to lateral spines, which are small and sharp; acumen long. Post-orbital ridge with sharp anterior spine. Carapace smooth and punctate above, grauulate on sides, lateral spine of moderate size, anterior lateral border notched just below the sub-orbital angle, which is not prominent. Areola linear for a short distance anterior to the centre, with a small anterior and a larger posterior triavgular field. The length of the areola is one half the distance from cervical groove to tip of rostrum. Abdomen as long as the cephalothorax. Proximal segment of telson bispinose on each side. Antenna nearly as long as the body. Lamina a trifle longer than rostrum, 
broad, greatest width at the middle, thence tapering to the long spine at apex. Third maxillipeds hairy within and below. Anterior process of epistoma truncate at apex. Chela broad, depressed, smooth and punctate belorv, ciliate-punctate above, margined on the outer edge. Inner margin of hand short, with a double row of small ciliated tubercles. Fingers of moderate length, straight, corneous and incurved at tip, costate and puuctato-ciliate above. Movable finger with outer edge furnished with a double row of ciliated tubercles on basal half. Outer finger hairy below at base of inner side. Carpus tuberculate above, with a strong and acute internal median spine, and a minute one at the base; smooth below, with two prominent anterior spines. Third pair of legs hooked. First pair of abdominal appendages articulated near the base, long, stout, strongly curved, bifid for a short distance from tip, rami divergent, outer one the longer.

Female. Annulus ventralis triangular, rounded anteriorly, posterior wall with a longitudiual sigmoid fissure. Sternum between fourth pair of legs smooth.

Length, $61 \mathrm{~mm}$. Antennæ, $52 \mathrm{~mm}$.

Twenty-five specimens of this species were collected for the U. S. National Museum by Mr. Edward Palmer, in a brook rumning into the eastern side of Red Foot Lake, near Idlewild Hotel, Obion Co., Tenn., May 30, 1882. The lot contains males of the second form, aud females. The rostrum, chele, and antennal scale are similar to those of $C$. viritis. It differs from that species in its linear shorter areola and male appendages, which are more strongly curved and formed more on the pattern of the same parts in $C$. immunis. In the latter species, however, these appendages are still more strongly curved, the areola is not linear in any part, the rostrum is more deeply excavated, longer, and (usually) toothless, the antennal scale is subtruncate at the end, and the hand different. Its closest relative is C. Mississippiensis. See description of that species.

Some of the specimens still show spots of dark color (purplish) on the chela, carpus, and branchial regions of the carapace. In a fer specimens there is a very faint indication of a mediau carina on the rostrum.

\section{C. Alabamensis, sp. nov.}

Male, form I. Rostrum broad, punctate, sub-excavated above at base, with a broar, rounded, slightly elevated median carina near the tip, sides sub-parallel, punctato-ciliate; acumen long, triangular, marginal spines slightly developed. Anterior spine of post-orbital ridge 
hardly developed. Carapace smooth, punctate, cervical groove sinuate, with minute lateral and branchiostegal spines; anterior margin notched at base of antennæ; areola wide, short (less than one half as long as the distance from cervical groove to the lateral rostral spiues), thickly punctate. Abdomen longer than the cephalo-thorax by the length of the terminal segment of telson. Telson rounded behind, basal segment bispinous. Epistoma triangular. Antennæ nearly as long as the body, slender; scale moderately broad, broadest in middle, thence tapering to the apical spine. Third maxillipeds hairy within and below. Chelipeds of moderate length, strong. Chela broad, thick, hand punctate, inner margin of morlerate length, scarcely serrate; fingers of moderate length, costate, ciliate-punctate, usually meeting only through their distal third. Immovable finger heavily bearded at base within, both above and below. Carpus smooth, punctate above; on the interual border there is a strong median spine, in front of this near the articulation is a minute spine, and behind it are one or two faint ones near the base; below, the carpus has a single small spine near the external articular point of the hand. Meros smooth, punctate, two obliquely-disposed spines near the anterior end of superior border; of the biserial spines beneath, only the distal one or two of the outer row are developed. Third pair of legs hooked at base. First pair of abdominal appendages long, deeply bifid, rami slender, recurved, parallel, inner ramus spoon-shaped at tip, outer ramus a little longer than the inner, compressed laterally, tapering to a fine point at tip.

Male, form II. Lateral rostral spines a little more prominent, hand smaller, hooks on third legs less strongly developed, first abdominal appendages thicker, bifid for only a short distance from the tip, rami laterally compressed, blunt-pointed.

Female. Rostrum as in the second form of the male, hand shorter and wider. Annulus ventralis with well-marked tranverse fossa.

Measurements of a male, form I.: - Length, $55 \mathrm{~mm}$. Carapace, $25 \mathrm{~mm}$. Abdomen, $30 \mathrm{~mm}$. Length of antennx, $50 \mathrm{~mm}$. Length of areola, $7 \mathrm{~mm}$. Breadth of areola, $2.5 \mathrm{~mm}$. Length of chela, $21 \mathrm{~mm}$. Breadth of chela, $9 \mathrm{~mm}$. Length of movable finger, $12.5 \mathrm{~mm}$.

A female of the same size has the areola $3 \mathrm{~mm}$. in width, $7 \mathrm{~mm}$. in length.

Forty specimens, including both forms of the male and the female, were collected by C. L. Herrick in Second Creek, Waterloo, Lauderdale Co., Ala., for the U.S. National Museum. The male appendages are very like those of $C$. Mississippiensis, the rami being longer and less strongly recurved than in $C$. immunis. It is at once distinguished by 
its broad and short areola from the other species in which the first abdominal appendages are formed after the pattern of those of $C$. im. munis. The section of the carapace behind the cervical groove is very short in this species, and the dense beard at base of the external finger is very characteristic. In $C$. compressus the areolia, although broad, is long, and the strong lateral compression of the body, different form of the chela, \&c., distinguish it at a glance from this species.

\section{C. Compressus, sp. nov.}

Male, form I. Rostrum narrow, excavated, curred downwards, with a longitudinal median carina; margius thickened, converging, with a line of ciliated dots; acumen long, triaugular, with acute lateral spines at base which are obsolescent in the largest specimens. Cephalothorax strougly compressed laterally. Post-orbital ridges armed with acute anterior spines. Carapace punctate on both the back aud sides; on the gastric region the punctation is very coarse, assuming the form of reticulation ; cerrical groove sinuate; no lateral or branchiostegian spines; anterior lateril margins notched behind the antennx; areola broad, heavily punctated. Abdomen ahout the length of the thorax. Telson long, proximal segment bispinose on each side. Antennre slender, shorter than the body by the length of the telson. Antennal scale of moderate width, terminal spine very long, reaching beyoul the tip of the rostrum. Epistoma triangular. External maxillipeds hairy within and below. Chelipeds short, stout; chels very large, broad, non-tuberculate, hand convex above and below, punctate, internal margin entire; fingers short, thick, with lines of ciliated dots. Carpus punctate above, with one internal median spine. Upper border of meros with one or two ante-apical spines; the biserial spines below are not devoloped, except the distal one of each row, and even these are minute. Third segment of third pair of legs hooked. First pair of abdominal appendages reach the base of the sccond pair of legs. They are deeply bific, the rami recurved; tho outer ramus is aciculate, the inner is enlarged at base and at tip, and the tip is furthermore grooved in front and rounded off at the end.

Male, form II. Hand smaller, fingers gaping at base, external finger ciliated at base within, hook on third segement of third lears very small ; first pair of abdominal appendages articulated near the base, thick, inner and outer parts separated for only a very small distance from apex, compressed from side to side, tips a little recurved, blunt-pointed. 
Female. Chele somewhat smaller than in the first form of the male, fingers less widely separated at base, external finger ciliated at base within. Anterior border of anuulus ventralis nearly obliterated in the median line, lateral borders raised into prominent tubercles, transverse fossa wide.

Leugth of body (male, form I.), $45 \mathrm{~mm}$. Length of carapace, $22.5 \mathrm{~mm}$. Length of areola, $8 \mathrm{~mm}$. Breadth of areola, $2 \mathrm{~mm}$.

In the largest specimen seen, the dimensions of which are given above, the lateral spines of the rostrum are obsolete, the margins simply notched at base of the acumen; in the other specimens the lateral rostral spines, though small, are evident; the antenna in the larger specimens are shorter in proportion to the length of the body.

Thirty-nine specimens (eighteen males, form I., two males, form II., and nineteen females) were collected by C. L. Herrick for the U. S. National MIuseum in Second Creck, Waterloo, and in Cyprus Creek, Lauderdale Co., Ala., October, 1882.

A small species with first abdominal appendages of the male similar to those of $C$. immunis. It is readily distinguished from all the other species with similar male appendages by the lateral compression of the cephalo-thorax, form of the chela, \&c.

\section{C. Sanbornit, sp. nov.}

Male, form I. Rostrum long, of moderate width, excavated, margins sub-parallel, lateral spine short, acute, brown-horny, acumen long, triangular, acute. Post-orbital ridges sulcate without, with acute anterior spines; carapace oval, flattened on the back, punctate, lightly granulate and ciliate on the sirles; antero-lateral margin notcherl behind the antennæ; cervical groove sinuate, interrupted on the sides just above the small acute lateral spine; areola of moderate width, punctate, dilated anteriorly and posteriorly. Abdomen as long as the body; posterior border of telson rounded, posterior border of basal segment bispinose on each side. Basal segment of antennule armed with an acute spine on internal border of lower sicle, near the apex. Antenne as long as the body, a small acute spine on the external side of second segment; scale a little longer than the rostrum, of moderate width, widest toward the middle, thence tapering to the acute terminal external spine. Anterior process of epistoma truncate in old specimens. Third pair of maxillipeds hairy within. Chelipeds short, chela broad, punctate above and below, inner margin with a double row of depressed squamous tubercles; all the puncta and tubercles of the hand give rise to pencils of fine downy cilia; 
fingers costate, punctate and ciliate, outer margin of movable finger furnished with low ciliate tubercles. Carpus broad, obliquely truncate, punctate and ciliate above, with a median internal spine; beneath, the carpus has an acute median anterior and a small external spine. Superior border of meros armed with two obliquely placed ante-apical spines; beneath ciliate; of the outer row of biserial spines only the distal spine is developed. Third segment of third pair of legs hooked. First pair of abdominal appendages short, somerwat twisted, bific at apex; rami short, thick, of nearly equal length, outer one sharppointed, brown-horny, inner one curved outwards and then inwards, flattened at apex.

Length, $69 \mathrm{~mm}$.

MIale, form II. First abdominal appendages articulated near the base, scarcely bifid, inuer and outer parts thicker than in first form, tips blunt, not brown-horny.

Female. Annulus ventralis depressed, anterior wall not prominent, posterior wall projecting backwards, a sinuous longitudinal fissure, transverse fossa olliterated.

Smoky Creek, Carter Co., Ky., and Oberlin, O.

Very closely related to. C. propinquus, but differs as follows: the rostrum is never carinate, the chela is pubescent, the inferior median anterior spine of the carpus is well developed; the first abdominal appendages, though very near those of $C$. propinquus, have the apical part shorter and less deeply bifid. These variations may perhaps be deemed of varietal rather than of specific value; but, aside from these specimens, I have seen so little variation in the very large number of C. propinquus examined, that I have decided to give the present form a special name.

I have examined many specimens, including the two forms of the male, females, and young, collected by the late F. G. Sanborn in Carter Co., Ky., and by Prof. B. F. Koons at Oberlin, O.

Small individuals closely resemble young specimens of $C$. propinquus, C. affinis, and more closely C. Putnami; but the young of the first may be distinguished by the carinated rostrum; of the second, by the longer rostral acumen, antennal scale, and anterior spine of postorbital ridge, by the longer hand and internal carpal spine, and by the divergent tips of the first pair of abdominal appentages in the male; of the third, by the longer-spined antennal lamina, the long, deeply-cleft abdominal appendages of the male, and the annulus ventralis of the female, which has a transverse fossa and bituberculate anterior wall.

vOL. XX. (N. S. XII.) 
One small specimen presents an interesting hermaphroditic condition. With the first abdominal appendages of the male is combined a wellformed annulus ventralis of the female!

\section{C. Harrisonit, sp. nov.}

Male, form I. Rostrum long, narrow, deflexed, excavated; margins thickened, a little couvergent; acumen of moderate length, triangular, acute; marginal spines short, obtuse, often obsolescent. Carapace flattened above, coarsely punctate, granulate on the sides; post-orbital ridges prominent, sulcate without, with acute anterior spine; antero-lateral margin notched at base of antenna; cervical suture not sinuate, interrupted on the side; lateral spine small, acute; branchiostegian spine obsolete; areola at least one half as long as the distance from the tip of the rostrum to the cervical groove, of moderate width, punctate, the dots tending to a biserial arrangement in the middle portion. Abdomen as long as the cephalo-thorax; telson long, posterior margin rounded, posterior margin of basal segment bispinous on each side. Basal segment of antennule with an internal, sub-apical, inferior spine. Antenua as long as the body; second segment armed with a short, acute, external spine; scale as long as the rostrum, of moderato wirlth, widest near the midlle, thence tapering to the acute external, apical spine. Anterior process of epistoma with convex sides, apex blunt or truncate. Third pair of maxillipeds hairy within. Chelipeds of moderate length, thick ; chela large, broad, coarsely punctate above and below, imer margin of hand with two or three rows of depressed ciliate tubercles; fingers costate and punctato-lineate, gaping, inner margins with rounded tubercles; movable finger incurved; carpus punctate above, armed with an acute median internal spine and two inferior spines (a large median and a minute external). In some specimens there are one or two small antennal basal tubercles. Meros smooth without, two obliquely-disposed superior sub-apical spines; of the biserial inferior spines only a few of the distal ones in each row are developed. Distal end of second pair of legs ciliate. Third segment of third pair of legs hooked. First pair of abdominal appendages short, reaching to the base of third pair of legs, thick, split for a short distance from the tip; outer part longer than the inner; tips recurved, brown-horny.

Female. Fingers less widely gaping, outer one ciliate within at base. Abdomen broader. Steruum between fourth thoracic legs, smooth. Annulus ventralis a transverse ridge, thickest in the middle, where there is a rounded tubercle dividerl longitulinally by a sinuous 
groove. Between the ridge and the sternal plates of the fourth pair of legs there is a deep transverse fossa.

Measurements of a male, form I.:- Length of body, $60 \mathrm{~mm}$. Length of carapace, $30 \mathrm{~mm}$. Length of abdomen, $30 \mathrm{~mm}$. From end of rostrum to cervical suture, $20 \mathrm{~mm}$. From cervical suture to posterior border of carapace, $10 \mathrm{~mm}$. Length of rostrum, $10 \mathrm{~mm}$. Breadth of rostrum at base, $4 \mathrm{~mm}$. Length of rostral acumen, $3 \mathrm{~mm}$. Width of areola, $1.5 \mathrm{~mm}$. Length of antennæ, $60 \mathrm{~mm}$. Length of chela, $25 \mathrm{~mm}$. Breadth of chela, $12 \mathrm{~mm}$. Length of movable finger, $17 \mathrm{~mm}$. Internal border of hand, $7 \mathrm{~mm}$.

In one specimen, a male, form I., the fingers are very much elongated, not gaping at base. The length of the internal border of the hand in this specimen is $7.5 \mathrm{~mm}$; the length of the movable finger, $21 \mathrm{~mm}$.

Irondale, Mo. Collected by E. Harrison.

This species resembles $C$. rusticus in its general form. 'The male appendages, as well as the annulus ventralis of the female, however, are very different from those of any previously described species. The male appendages approach in form those of $C \cdot$ propinquus more nearly than any other, but in that species these appeudages are more deeply bifid, and not recurved.

The second form of the male is unknown.

\section{C. Putnami, sp. nov.}

Male, form I. Rostrum broad, sub-excavated, margins nearly parallel, with a line of ciliated puncta; acumen long, equal in length to the width of base of rostrum, narrow, acute, with a black, horny tip and lateral spines. Post-orbital ridges sulcate on external side, inflated at posterior end, armed with a sharp, horny-tipped auterior spine. Carapace long-oval, slightly flattened above, heavily punctated, sides rough with ciliated granules; cervical groove deep, lightly sinuate, broken on the sides just above the small, acute lateral spine; branchiostegian spine slightly developed; anterior lateral margins angulated, but without sub-orbital spine. Posterior segment of carapace equal in length to one half the distance from tip of rostrum to cervical groove. Areola of moderate width, punctated. Abdomen as long as cephalo-thorax, pleurx punctate, telson bispinose on each side. Anterior process of epistoma ciliated, triangular, siles convex, marginated. Basal segment of antennule armed below with an internal ante-apical spine. Antenna slender, about as long as the body, scale as long as the rostrum, of moderate width, external border inflated, 
ending in a sharp spine. Third maxillipeds hairy within and below. Chelipeds stout; chela large, external margin convex; hand ciliatopunctate above and below (the dots large), swollen above, internal border of moderate length and furnished with two or three rows of depressed ciliate tubercles; fingers gaping at base, at least in large individuals, costate and punctate-lined, external margin of movable finger with depressed ciliated tubercles irregularly disposed in two rows; tips of fingers incurved, horny. Carpus smooth or faintly tuberculate above, a large, acute median internal spine, and small proximal and distal internal spines; beneath, the carpus has a very minute or no median anterior spine, a short and acute external spine. Meros with two superior, obliquely placed ante-apical spines; of the ordinary biserial inferior spines only the distal one or two of the outer row are developed. Third pair of legs hooked on third segment. Thoracic sterna hairy. First pair of abdominal appendages very long, reaching the base of the chelipeds when the abdomen is flexed, tuberculated on internal border at the base, deeply bifid, rami slender, acute, forming an acute angle with the basal part, the outer slightly recurved, the inner shorter, incurved, and a little dilated before the tip; a projecting angle or shoulder on the anterior border at base of rami.

Male, form II. Chela smaller, fingers not gaping, hook on third segment of third pair of legs smaller ; first pair of abdominal appendages split only half as far down as in the first form, rami much thicker, no projecting angle on the anterior border; these appendages are as long as in the first form, reaching forward to the base of the chelipeds; they are articulated near the base.

Female. Chela shorter and wider, external finger bearded within at base; sternum between fourth pair of legs non-tuberculate, lightly ciliate. Annulus ventralis large, transverse fossa broad and deep, anterior border bituberculate.

Measurements of a male, form I.: - Length of body, $73 \mathrm{~mm}$. Length of carapace, $36 \mathrm{~mm}$. From tip of rostrum to cervical groove, $24 \mathrm{~mm}$. From cervical groove to hind border of carapace, $12 \mathrm{~mm}$. Length of rostrum, $11 \mathrm{~mm}$. Breadth of rostrum at base, $4.5 \mathrm{~mm}$. Length of acumen of rostrum, $4 \mathrm{~mm}$. Width of areola, $2.5 \mathrm{~mm}$. Length of abdomen, $37 \mathrm{~mm}$. Length of chela, $34 \mathrm{~mm}$. Breadth of chela, $14 \mathrm{~mm}$. Length of movable finger, $22 \mathrm{~mm}$.

Known localities. Kentucky: Grayson Springs, Grayson Co.; Green River, near Mammoth Cave; Cumberland Gap.

M. C. Z., Cat. No. 3574 (young female), from Knoxville, Tenn., 
Walter Faxon, and Cat. No. 3575 (male, form II.), from Bradford, Ind., A. S. Packard, Jr., probably belong to this species, but the specimens are too young to determine with confidence.

This species resembles $C$. spinosus, from which it is easily distinguished by the length of the posterior section of the carapace, and by the length of the male appendages. From $C$. affinis it may be separated by the different form of the male appendages and female annulus ventralis, and by the single lateral spine of the carapace. I have seen males of the first form only $34 \mathrm{~mm}$. in length.

\section{C. Forceps, sp. nov.}

Nale, form I. Rostrum narrow, excavated, faintly carinated in the middle ; margins divergent at the base, thickened, dotted-lined ; acumen long and narrow, horny tipped; lateral spines small. Post-orbital ridges not very prominent except anteriorly, where they terminate in a spine with a corneous tip. Carapace cylindroidal, punctate above, granulated on the sides, antero-lateral margins bluntly angulated; cervical groove sinuate; small and acute lateral spine: no branchiostegian spine; areola of moderate width, punctate. Abdomen as long as the cephalo-thorax: telson rounded behind, bispinose on each side. Epistoma smooth, anterior process triangular, in some specimens truncate. Thoracic sterna with silky setæ at bases of the legs. Antennæ slencler, as long as the body; scale a little longer than the rostrum, of moderate width, sub-truncate at distal end, outer margin ending in a long, sharp, somewhat outwardly directed spine. Third pair of maxillipeds hairy within. Chelipeds short, stout; chelæ large, wide, with slender cylindrical, widely-gaping fingers, which are curved outward at the base and opposable only at their tips; hand thickly punctated above and below, inner margin obscurely serrate; fingers naked at base, with parallel rows of eiliated dots; a dark band around both the inner and outer fingers a little distance from the tip. Carpus punctate above, a strong, sharp internal median spine; below there is no anterior median spine, and only a very minute external one. Meros short; of the biserial inferior spines only the distal one in each row is usually developed to any extent; above there are commonly two obliquely placed ante-apical spines, in some specimens only one. Distal portion of the following pairs of legs furnished with long sete, especially long on the second pair of legs. Third segment of third pair of lega hooked. First pair of abdominal appendages long, deeply bitil, rami slemter, straight, parallel, the outer a little longer than the inner, and a little recurved at the tip. In some specimens the anterior border at the 
base of the rami has a projecting angle or shoulder, but in most specimens this is not evident.

Female. Fingers straighter. Base of external finger has a dense beard on the inside; in a ferw of the specimens seen the fingers are longer, nearly straight, their opposed margins almost meeting throughout their length. Annulus ventralis bilaterally symmetrical, anterior margin bituberculate, posterior margin unituberculate, fossa transrerse.

Dimensions of a male, form I. : - Length of body, $38 \mathrm{~mm}$. Length of carapace, $19.5 \mathrm{~mm}$. Length of abdomen, $18.5 \mathrm{~mm}$. From tip of rostrum to cervical groove, $14 \mathrm{~mm}$. From cervical groove to posterior border of carapace, $6 \mathrm{~mm}$. Length of rostrum. $5 \mathrm{~mm}$. Length of acumen of rostrum, $2 \mathrm{~mm}$. Width of areola, $1 \mathrm{~mm}$. Length of antenna, $36 \mathrm{~mm}$. Length of chela, $16 \mathrm{~mm}$. Breadth of chela, $7.5 \mathrm{~mm}$. Length of movable finger, $10.5 \mathrm{~mm}$.

The largest female specimen is 60 millimeters in length.

Cyprus Creek, Lauderdale Co., Ala.

Nine specimens, four males of the first form and five females, collected by C. L. Herrick for the U. S. National Museum, October, 1882.

This is a small species with large hand, slender fingers widely separated at base and meeting only at the tips. In the female, there is a heavy beard at base of external finger on the inner side.

In the summer of 1872 I collected in a brook at Knoxville, Tenn., six specimens, three second form males and three females, which closely resemble those obtained by Mr. Herrick in Alabama, and belong, I think, to the same species. The external finger of the males is densely bearded within at the base, as in the females from Lauderdale Co., Ala., the first abdominal appendages reach forward to the base of the second pair of legs, are bifid at the tip, the internal and external parts are thick, blunt at the tip, the outer somewhat longer than the inner, and slightly recurved at the tip.

\section{§5. Second and third pairs of legs of male houked.}

\section{C. Shufeldtir, sp. nov.}

Male, form I. Rostrum plane above, margins a little convergent, raised into a slight rim from the base to the lateral spines, which are prominent and acute; acumen of morlerate length, acute, pubescent. Post-orbital ridges with anterior spines. Carapace smooth, a sharp spine on the cervical groove on each side; sub-orbital angle prominent, branchiostegiau spine present. Areoli of moderate breadth. Telson bispinous on each side. Epistoma triangular. Antennal scale broad. 
Hand smooth, cylindrical, inflated; fingers slender, incurved at the tips. Carpus smooth, armed with a single spine on the antero-inferior border. Meros provided with a single spine near the distal end of the superior margin and two or three below. Third segment of second and third pairs of legs hooked. First pair of abdominal appendages straight, bifid, inner part ending in a straight, acute tip, outer part split at the tip into two straight acute points.

In the second form of the male the hooks upon the thoracic legs are very slightly developed, and the first alxdominal appendages are less deeply cleft, with blunter and less finished tips. The chela is shorter.

In the female the chela is much shorter, broader, and less cylindrical, the abdomen broader. Annulus ventralis a transverse curved ridge, the hind side of the ridge concave.

Length, 19 to $27 \mathrm{~mm}$.

Locality. Near New Orleans, La.

Found with C. Clarkii in the collection made by Dr. R. W. Shufeldt, U. S. A., in 1883, now in the U. S. National Museum.

This is a minute species closely related to C. Montezuma from Mexico. Like that species, it has the second and third pairs of legs hooked in the male, a condition which normally obtains in no other species known.* C. Shufeldtii is distinguished from C. Montezume by the presence of a lateral spine on the carapace and by the form of the male appendages. In the latter species the tips of these appendages are recurved, the inner part flattened at the end into a spoon-shaped surface. In $C$. Shufeldtii the tips of these organs are straight, and each of the three points in which they terminate is acute.

LIST OF THE KNOIVN SPECIES OF CAMBARUS AND ASTACUS.

1. Cambarus Blandingit.

Astacus Blandingii, Harlan, Trans. Amer. Philosoph. Soc., III. 464. 1830. — Med. and Phys. Res., p. 229, fig. 1. 1835. Astacus (Cambarus) Blandingii, Erichson, Arch. Naturgesch., Jahrg. XII., Bd. I., 98. 1846.

? Astacus Blandingii, Le Conte, Proc. Acad. Nat. Sci. Phila. VII. 400. 1855.

* I lave seen two or three abnormal specimens of $C$. virilis and $C$. propinquus with a like disposition of hooks on the legs. 
Cambarus Blandingii, Hagen, Ill. Cat. Mus. Comp. Zoöl., No. III. 43, Pl. I. figs. 63, 64, Pl. III. tig. 140. 1870.

Cambarus acutus, var. B, Hagen, op. cit., p. 36, Pl. III. fig.

144. 1870.

Cambarus acutus, Abbott, Amer. Nat., VII. 80. 1873 (habits).

Hab. New Jersey, Maryland, Virginia, North Caroliua, South Carolina, Georgia.

a. Var. acuita.

Cambarus acutus, Girard, Proc. Acad. Nat. Sci. Phila., VI. 91. 1852.

Cambarus acutissimus, Girard, $l$. $c$.

Cambarus acutus, Hagen, op. cit., p. 35, Pl. I. figs. 1-5, Pl. II. figs. $106,108,110-114,116,118,120-124,126,127$, Pl. III. fig. 143. 1870.

Cambarus acutus, var. A, Hagen, op. cit., p. 36, Pl. II. figs. 107, 109, 115, 117, 119, 125.

Cambarus acutus, Forbes, Bull. Ill. Mus. Nat. Hist., No. I. pp. 3, 18. 1876.

Hab. Louisiana, Mississippi, Alabama, South Carolina, Tennessee, Missouri, Illinois, Indiana, Iowa, Wisconsin.

2. Cambarus fallax.

Cambarus fallax, Hagen, op. cit., p. 45, Pl. I. figs. 103-105. 1870.

Hab. Florida.

3. Cambarus Hayi.

Cambarus Hayi, Faxon, supra, p. 108.

Hab. Mississippi.

4. Cambarus Clarkit.

Cambarus Clarkii, Girard, op. cit., p. 91. 1852.

Cambarus Clarkii, Hagen, op. cit., p. 39, Pl. I. figs. 7-10, 99, 100, Pl. II. figs. 133, 134, Pl. III. fig. 142, Pl. IV. 1870.

Hab. Texas, Louisiana, Mississippi, Alabama, Florida.

5. Cambarus troglodttes.

Astacus troglodytes, Le Conte, op. cit., p. 400. 1855.

Astacus fossarum, Le Conte, op. cit., p. 401. 1855.

Cambarus troglodytes, Hagen, op. cit., p. 41, Pl. I. figs. 11-14, Pl. II. fig. 141. 1870 .

Hab. Georgia, South Carolina.

Noте.-Girard and Gibbes confounded this species with C. Blandingii. Gibbes distributed specimens of C.troglodytes under the name of Astacus Blan- 
dingii, and the localities for $C$. Blandingii given by Girard and Gibbes probably appertain to C. troglodytes. The dry specimen in the MIuseum of Comparative Zoölogy (No. 3337) labelled "Rocky River, Olmsted, Ohio," determined as C. troglodytes by Hagen (op. cit., p. 43), is C. Clurkii. 'The labels of dry specimens are easily transposed, and $I$ believe this locality to be erroneous. There is an alcholic specimen of C. troglodytes in the same Museum (No. 197) labelled "Lawn Ridge, Ill." No other specimens have been reported from the West, ind I doubt the accuracy of the locality label of this specimen. Specimens from Richmond Co., Ga., lately received from Col. C. C. Jones, Jr., approach $C$. Clarkii in the shape of the male appendages, while in the form of the rostrum and other respects they agree with $C$. troglodyles. Judging from these specimens, I believe that further explorations will break down the specific distinctions between these two forms. But my material is not sufficient for a definite opinion.

\section{Cambarus maniculatus.}

Astacus maniculatus, Le Conte, op. cit., p. 401. 1855.

Cambarus maniculatus, Hagen, op. cit., p. 52. 1870 (after Le Conte).

Hab. Lower Georgia.

Known only through Le Conte's description, which perhaps was drawn up from an immature specimen of $C$. troglodytes.

\section{Cambarus Lecontei.}

Cambarus Lecontei, Hagen, op. cit., p. 47, Pl. I. figs. 15-18, Pl. III. fig. 145. 1870 .

Hab. Georgia, Alabama.

The specimens from Beaufort, N. C., and Root Pond, Miss., referred to $C$. Lecontei by Hagen, are C. Blandingii. Three young specimens from Pensacola, Fla. (M. C. Z., No. 249), are also placed here by Hagen, but the justice of the determination seems doubtful. They do not agree well with the types from Mobile.

8. Cambarus angustatus.

Astacus angustatus, Le Conte, op. cit., p. 401. 1855.

Cambarus angustatus, Hagen, p. 50, Pl. I. figs. 65-67, Pl. III. fig. 146. 1870.

Hab. Lower Georgia.

Known only through a single type specimen in the Acal. Nat. Sei. Phila.

9. Cambarus pubescens.

Cambarus pubescens, Faxon, supra, p. 109.

Hab. Georgia. 
10. Cambarus spiculifer.

Astacus spiculifer, Le Conte, op. cit., p. 401. 1855.

Cambarus spiculifer, Hagen, op. cit., p. 18, Pl. I. figs. 59-62, Pl. III. fig. 147. 1870.

Hab. Upper Georgia.

11. Cambarus versutus.

Cambarus versutus, Hagen, op. cit., p. 51, Pl. I. figs. 55-58, Pl. III. fig. 150. 1870.

Hab. Neighborhood of Mobile, Ala. Cape Barrancas, Fla.

12. Cambarus Atceni.

Cambarus Alleni, Faxon, supra, p. 110.

Hab. Florida.

13. Cambarus penicillatus.

Astacus penicillatus, Le Conte, op. cit., p. 401. 1855.

Cambarus penicillatus, Hagen, op. cit., p. 53, Pl. I. figs. 93, 94, [95, 96 ?], Pl. III. fig. 149. 1870.

Hab. Georgia, Mississippi? South Carolina?

Two young female specimens from Charleston, S. C. (M. C. Z., No. 254), referred by Hagen to $C$. penicillatus, are $C$. troglodytes. Two other females, and two second form males, also from Charleston, in the same collection (No. 250), may be the female and second form of the male of $C$. penicillatus, to which they are referred by Hagen; but they differ in so many respects, that I suspect they belong to another species. In the collection of Prof. O. P. Hay of Butler University, Irvington, Ind., there is a second form male from Eastern Mississippi, which with some doubts I have referred to this species. More material must be obtained before the specific characters can be accurately given.

14. Cambarus Wiegmanni.

Astacus (Cambarus) Wiegmanni, Erichson, op. cit., p. 99. 1846.

? Cambarus Wiegmanni, Hagen, op. cit., p. 54, Pl. III. fig. 151. 1870.

Hab. Mexico.

The types of Erichson's two Mexican species of Cambarus, C. Wiegmanni and $C$. Mexicanus, could not be found in the Berlin ALseum, either by Hagen, who examined the collection in September, 1870, or by Von Martens (Arch. Naturgesch., 1872, p. 131). C. Wiegmanni alone of the known Mexican species belongs to the $C$. Blandingii group, with hooks on the third and 
fourth pairs of legs in the male. The female specimen in the Acad. Nat. Sci. Phila. (No. 170, Mr. Pease), fully described by Hagen, is probably correctly referred to this species by him, although in the absence of male specimens there is some uncertainty. I have seen but one specimen of $C$. Mexicanus, a male. In this the chele are more cylindrical, and are covered with smaller, more closely set, granular tubercles. In the collection of Acad. Nat. Sci. Phila., I find another alcoholic female from Jalapa, Mexico, which agrees well with Mr. Pease's specimen. A mutilated female in the U. S. Nat. Mus. (No. 3288), collected by Sumichrast at the Isthmus of Tehuantepec, seems also to belong here.

15. Cambarus pellucidus.

Astacus pellucidus, Tellkampf, Arch. Anat. Plıysiol. u. wissensch. Med., 1844, p. 383.

Astacus (Cambarus) pellucidus, Erichson, op. cit., p. 95. 1846.

Cambarus pellucidus, Girard, op. cit., p. 87. 1852.

Cambarus pellucidus, Hagen, op. cit., p. 55, Pl. I. figs. 68-71, PI. III. fig. 148, Pl. VI. 1870.

Orconectes pellucidus, Cope, Amer. Nat., VI. 410, 419. 1872. -3d and 4th Ann. Rep. Geolog. Surv. Ind., pp. 162, 173. 1872.

Orconectes inermis, Cope, Amer. Nat., VI. 410, 419. 1872.3d and 4th Ann. Rep. Geolog. Surv. Ind., pp. 162, 173. 1872.

Hab. Mammoth Cave and other caves in Edmonson Co., Ky., Wyandot Cave, Ind., and cave in Bradford, Harrison Co., Ind.

The Indiana specimens do not differ enough from the typical form from Mammoth Cave to be considered a distinct species, as Cope would have us believe. I have seen the same form from Mammoth Cave.

In the Berliner Entomologische Zeitschrift, XXVI. 12-14, April, 1882, Gustav Joseph imperfectly describes under the name Cambarus Strgius a blind Crayfish, very closely related to $C$. pellucidus, said to have come from the caves of Carniola! In the earliest notice of this startling discovery in 57th Jahresber. Schles. Gesellsch. vaterlïnd. Cultur, 1879, p. 202, Breslau, 1850, the new species is called Cambarus typhlobius. In a paper published in December, 1881, in Berliner Entomol. Zeitschr., XXV., Joseph again mentions, without describing, the animal under the names Cambarus coecus (p. 237) and C. Siygius (pp. 241, 249). Until a more satisfactory account of this discovery 
is published, one may well hesitate to admit the Carniola Cambarus into the list.

Cajrbares Strgrus, Bundy, Bull. Ill. Mus. Nat. Hist., No. I. p. 3, 1876, Trans. Wis. Acad. Sci., V. 180, 1882, Geol. Wis., Surv. 1873-1879, I. 402, 1883, a species founded on mutilated specimens (the fourth thoracic legs of the males being lost), is indeterminable. It is said to be "closely related to $C$. acutus, but may be at once separated by the shorter hands, - similar to those of C.propinquus, - and the non-tuberculated annulus of the female." Shore of Lake Michigan, Racine, Wis.

16. Cambarus simulans.

Cambarus simulans, Faxon, supra, p. 112.

Hab. Texas, Kansas.

17. Cambarus advena.

Astacus advena, Le Conte, op. cit., p. 402. 1855.

Cambarus Carolinus, Hagen, op. cit., p. 87, Pl. I. figs. 51-54, Pl. III. fig. 165.1870.

Cambarus advena, Hagen, op. cit., Pl. III. fig. 164, Pl. VII. 1870.

The descriptions of $C$. advena and $C$. Carolinus in Hagen's monograph are accideutally transposed, so that they do not agree with Hagen's types in the Museum of Comparative Zoölogy. A full figure of Le Conte's species is given as C.advena on Plate VII., and the antennal scale, spine of the second segment of the antenna, and epistoma (from Le Conte's type in the Philadelphia Academy) on Pl. III. fig. 164. The male appendages, antennal scale, and epistoma are figured on Pl. I. figs. 51-54, Pl. III. fig. 165, as C. Carolinus.

18. Cambarus Carolinus.

? Astacus (Cambarus) Carolinus, Erichson, op. cit., p.96. 1846.

Cambarus advena, Hagen, op. cit., p. 86, Pl. I. figs. 90-92. 1870.

Cambarus Carolinus, Hagen (as determined by examination of his type specimen!).

Hab. South Carolina.

For the transposition of the descriptions and part of the figures of C. advena and C. Carolinus in Hagen's Monograph, see above. Hagen's type of $C$. Carolinus, labelled, "Cambarus Caro-

* This figure represents a female (M. C. Z., No. 282), not male, as stated on the plate and in the text. 
linus Er.," and described by him (p. 86) as C. advena Le Conte, is a first form male (M. C. Z., No. 232) from Charleston, S. C. The distinctions noted by Hagen, based on the presence or absence of spines on the lower side of the first segment of the antennule and at the end of the cervical groove, I do not find to hold good. The statement that "in the larger specimens the hand is more sulcater beneath at the inner margin, and the carpus more spinulose," probably refers to Le Conte's type of $C$. advena in the Philadelphia Academy. The female in the same jar with the male type above noticer differs from the male in so many respects that I doubt whether Hagen has correctly referred it to the same species. All the other specimens in the Museum determined as C. Carolimus by Hagen are small specimens. No. 3368, dry female from Georgia, L. Agassiz, is certainly $C$. advena. No. 3367 (1850 of Hagen), a young female, also from Georgia, resembles $C$. advena in most respects, but the antennal scale is too broad near the tip. No. 280 , young female specimens from Mobile, Ala., and No. 275, a very young male from the same locality, appear to belong to some species allied to $C$. Bartonii, the tips of the male appendages being strongly recurved. Dr. Hagen examined Erichson's type, a male, form I., in Berlin, in 1870, and thought it was $C$. Bartonii. Erichson's description, nevertheless, fits the present species very well. The structure of the male appendages of Erichson's type would at once prove or disprove its identity with $C$. Bartonii. If it be really $C$. Bartonii, the species under consideration must receive a new name, C. Hagenianus.

19. Cambarus gracilis.

Cambarus gracilis, Bundy, Bull. Ill. Mus. Nat. Hist., No. I., p. 5. 1876. - Trans. Wis. Acad. Sci, V. 182. 1882. - Geol. Wis., Surv. 1873-1879, I. 403. 1883.

Hab. Wisconsin, Iowa, Illinois.

20. Cambarus Mexicanus.

Astacus (Cambarus) Mrexicanus, Erichson, op. cit., p. 99. 1846.

? Cambarus Aztecus, Saussure, Rev. et Mag. de Zool., $2^{\circ}$ Sér., IX. 503. 1857. - Mém. Soc. Phys. Hist. Nat. Genève, XIV. 460, Pl. III. fig. 23. 1858.

Cambarus Mexicanus, Hagen, op. cit., p. 84. 1870 (after Erichson).

Hab. Mexico.

I have seen one specimen (a male) in the Philadelphia Academy, which agrees with Erichson's description. It comes from 
Mirador, Mexico. C. Aztecus Saussure has (according to the description) a shorter, flatter hand, and carpus spinous on internal border. Von Martens (Arch. Naturgesch., XXXVIII. 131) would separate it from C. Mexicanus. Dr. Hagen has kindly given me the following note on the types of Saussure in the Berlin Museum: "The first form of the male, and the female, from Mexico, seem to be C. Mexicanus Erichs., with nearly cylindrical hands. The second form, with more flattened hands, belongs alone, then, to Saussure's C. Aztecus. In the second form the antennal scale is more broadly truncate in front, and the rostrum is a little different, but the differences are not striking enough to preclude the identity." Erichson's types of $C$. Mexicanus were not found. Saussure's locality for C. Aztecus is near Tomatlan "dans les Terres-Chaudes." According to Von Martens there are specimens in the Berlin Museum from Puebla.

21. Cambarus Cubensis.

Astacus (Cambarus) Cubensis, Erichson, op. cit., p. 100. 1846. ?Cambarus consobrinus, Saussure, Rev. et Mag. de Zool., $2^{\circ}$ Sér., IX. 101. 1857.- Mém. Soc. Phys. Hist. Nat. Genève, XIV. 457, Pl. III. fig. 21.1858.

Cambarus Cubensis, Hagen, op. cit., p. 85.1870 (after Erichson).

Cambarus Cubensis, Von Martens, Arch. Naturgeschichte, XXXVIII. 129. 1872.

Hab. Cuba.

Erichson's and Saussure's types are in the Berlin Mruseum, and have been examined by Hagen and Von Martens. Saussure's C. consobrinus are two dry female specimens. They differ in some unimportant regards from Erichson's $C$. Cubensis, and, as the male appendages of Saussure's species are not described, the identity of the tro species is somewhat doubtful. According to Von Martens, specimens in the Berlin Museum indicate the presence of two species in Cuba. The examples of $C$. Cubensis in the Mruseum of Comparative Zoölogy were taken by MIr. Samuel Garman from creeks near Havana.

22. Cambarus Bartonil.

? Astacus Bartonii, Fabricius, Suppl. Entomolog. Syst., p. 407. 1798.

?Astacus Bartonii, Bosc, Hist. Nat. Crust., II. 62, Pl. XI. 1802. Astacus ciliaris, Rafinesque, Amer. Monthly Mag., II. 42. Nov., 1817. 
?Astacus pusillus, Rafinesque, op. cit., p. 42.

Astacus Bartonii, Say, Journ. Acad. Nat. Sci. Phila., I. 167. Dec., 1817.

Astacus Bartonii, Harlan, Med. and Phys. Res., p. 230, fig. 3. 1835.

? Astacus affinis, Milne Edwards, Hist. Nat. Crust., II. 332. 1837.

Astacus Bartonii, Gould, Rep. Invert. Mass., p. 330. 1841.

Astacus Bartonii, Thompson, Hist. Vermont, Part I. p. 170. 1842.

Astacus Bartoni讠, De Kay, Zoöl. N. Y., Part VI., Crustacen, p. 22, Pl. VIII. fig. 25.1844.

Cambarus Bartonii, Girard, op. cit., p. 88. 1852.

Cambarus montanus, Girard, op. cit., p. 88.

? Cambarus longulus, Girard, op. cit., p. 90.

? Cambarus pusillus, Girard, op. cit., p. 90.

Cambarus Bartonii, Hagen, op. cit., p. 75, Pl. I. figs. 47-50, Pl. II. figs. 135-139, Pl. III. fig. 166. 1870.

Cambarus Bartonii, Abbott, op. cit., p. 80. 1873 (habits).

Hab. New Brunswick; Province of Quebec? Maine, Vermont, Massachusetts, New York, New Jersey, Pennsylvania, Maryland, District of Columbia, Virginia, West Virginia, North Carolina, Ohio, Indiana, Lake Superior, Kentucky, Tennessee.

In the Museum of Comparative Zoölogy are specimens of C. Bartonii labelled, "Osage River, G. Stolley" (No. 183) ; but this locality is marked by Dr. Hagen as being very doubtful. Another specimen (No. 3358) is ticketed, "Charleston, S. C.?" and three specimens (No. 1101) in the same jar with an Alpheus are marked, "Pico, Azores, Miss O. Dabney, May 23, 1860." The latter locality, at auy rate, is doubtless erroneous. Hagen states that he has seen a specimen from Georgia, and I find in the collection of the Boston Society of Natural IHistory this species in the same bottle with a Pugurus and Hyas coarctatus, labelled, "Sarannah, Ga., Dr. H. Bryant." The presence of the marine forms, especially the Northern Hyas, casts doubt on the correctness of the label.

As might be expected of a species with such a wide geographical range, $C$. Bartonii presents many variations of form.

23. Cambarus robustus.

Cambarus robustus, Girard, op. cit., p. 90. 1852.

Cambarus robustus, Hagen, op cit., p. 80, Pl. III. fig. 167. 1870 . 
Hab. Neighborhood of Toronto, Province of Ontario; New York, Maryland, Virginia, Illinois.

24. Cambarus acuminatus.

Cambarus acuminatus, Faxon, supra, p. 113.

Hab. Saluda River, South Carolina; Western North Carolina.

25. Cambarus latmanus.

? Astacus (Cambarus) Bartonii, Erichson, op. cit., p. 97. 1846. Astacus latimanus, Le Conte, op. cit., p. 402. 1855.

Cambarus latimanus, Hagen, op. cit., p. 83, Pl. I. figs. 43-46, Pl. III. fig. 162.1870.

Hab. South Carolina, Georgia, Alabama, Mississippi, Tennessee (var.).

Erichson's types of $C$. Bartonii were examined by Dr. Hagen in 1870 , and judged to be $C$. latimanus.

\section{Cambarus Diogenes.}

Cambarus Diogenes, Girard, op. cit., p. 88. 1852.

C'ambarus obesus, Hagen, op. cit., p. 81, Pl. I. figs. 39-42, Pl. III. fig. 163, Pl. IX. 1870 .

Hab. New Jersey, Maryland, District of Columbia, Virginia, North Carolina, Ohio, Indiana, Illinois, Michigan, Wisconsin, Iowa, Missouri, Kansas, Colorado, Wyoming, Arkansas, Kentucky? Mississippi.

The labels of specimens, probably types, of $C$. propinquus and $C$. Diogenes, in the Philadelphia Academy, have been transposed.

Var. Ludoviciana.

Hab. Louisiana.

This variety, received from New Orleans, differs in having a narrower rostrum, with parallel margins, and more acute tip.

The burrowing habits of $C$. Diogenes are described by Girard, l. c., and recently by R. S. Tarr in Nature, XXX. 127, and C. C. Abbott in Amer. Nat., XVIII. 1157. The curious "chimneys " at the mouth of the burrows are figured by Audubon, Birds of America, Pl. 360, 370 (4to ed.).

27. Cambarus argillicola.

Cambarus argillicola, Faxon, supra, p. 115.

Hab. Toronto, Province of Ontario ; Michigan, Indiana, Louisiana? North Carolina? 
28. Cambarus dubius.

Cambarus dubius, Faxon, supra, p. 114.

Hab. Mountain region of West Virginia, Virginia, and Tennessee.

29. Cambarus Nebrascensis.

Cambarus Nebrascensis, Girard, op. cit., p. 91. 1852.

Cambarus Nebrascensis, Hagen, op. cit., p. 83.1870 (after Girard).

Hab. Fort Pierre, Dakota.

This species is unknown to me. Possibly it is a form of C. Diogenes.

30. Cambarus Uhleri.

Cambarus Uhleri, Faxon, supra, p. 116.

Hab. Lowlands of Maryland.

31. Cambarus extraneus.

Cambarus extraneus, Hagen, op. cit., p. 73, Pl. I. figs. 88, 89, Pl. III. fig. 156. 1870.

Hab. Tennessee River, near the border of Georgia; Etowah River, Rome, Georgia.

The larger female mentioned by Hagen, p. 74, is $C$. spinosus Bundy.

32. Cambarus Girardiands.

Cambarus Girardianus, Faxon, supra, p. 117.

Hab. Cyprus Creek, Lauderdale Co., Alabama.

33. Cambarus Jordani.

Cambarus Jordani, Faxon, supra, p. 119.

Hab. Etowah River, Rome, Georgia:

34. Cambarus cornutus.

Cambarus cornutus, Faxon, supra, p. 120.

Hab. Green River, near Mammoth Cave, Kentucky.

35. Cambarus mamulatus.

Orconectes hamulatus, Cope and Packard, Amer. Nat., XV. 881, Pl. VII. figs. $1,1 a, 1$ b. Nov., 1881.

Hab. Nickajack Cave, Tennessee.

I am indebted to Prof. A. S. Packard for the opportunity to examine six type specimens (four males, form II, and two females) of this interesting blind species.

36. Cambarus medius.

Cambarus medius, Faxon, supra, p. 121.

Hab. Irondale, Missouri.

voL, $\mathrm{xx},($ N. S. XII.) 
37. Cambarus murnis.

Cambarus immunis, Hagen, op. cit., p. 71, PI. I. figs. 101, 102, Pl. III. fig. 160, Pl. VIII. fig. b. 1870 (male, form I., and female). Cambarus immunis, Forbes, op. cit., pp. 4, 19. 1876 (male, form II., and young).

Cambarus immunis, Bundy, Proc. Acad. Nat. Sci. Phila., 1877, p. 171.

Cambarus signifer, Herrick, 10th Ann. Rep. Geolog. Surv. Minn., p. 253.1882.

Hab. New York, Indiana, Illinois, Michigan, Wisconsin, Minnesota, Iowa, Missouri, Kansas, Wyoming, Alabama, and Orizaba, Mexico.

a. Var. spinirostris.

Hab. Obion Co., Tennessee.

In this form the rostrum possesses lateral spines at the base of the acumen.

38. Cambarus Mississippiensis.

Cambarus Mississippiensis, Faxon, supra, p. 123.

Hab. Eastern Mississippi.

39. Cambarus Palmeri.

Cambarus Palmeri, Faxon, supra, p. 124.

Hab. Obion Co., Tennessee.

40. Cambarus Arabayensis.

Cambarus Alabamensis, Faxon, supra, p. 125.

Hab. Lauderdale Co., Alabama.

41. Cambarus compressus.

Cambarus compressus, Faxon, supra, p. 127.

Hab. Lauderdale Co., Alabama.

42. Cambarus lancifer.

Cambarus lancifer, Hagen, op. cit., p. 59, Pl. I. figs. 86,87 , Pl. III. fig. 159. 1870.

Hab. Mississippi.

Hagen's type remains unique.

43. Cambarus affinis.

? Astacus limosus, Rafinesque, op. cit., p. 42. Nov., 1817. Astacus affinis, Say, op. cit., p. 168. Dec., 1817.

Astacus affinis, Harlan, Med. and Phys. Res., p. 230, fig. 2. 1835.

Astacus Bartonii, Milne Edwards, op. cit., II. 331. 1837. 
? Astacus (Cambarus) affinis, Erichson, op. cit., p. 96. 1846.

Cambarus affinis, Girard, op. cit., p. 87. 1852.

Cambarus Pealei, Girard, op. cit., p. 87. 1852.

Cumburus affinis, Hagen, op. cit., p. 60, Pl. I. figs. 19-22, 84, 85, Pl. III. fig. 152, Pl. V. 1870.

Cambarus affinis, Abbott, op. cit., p. 80. 1873 (habits).

Hab. New York, New Jersey, Pennsylvania, Maryland, District of Columbia, Virginia, Lake Erie, Lake Superior.

Erichson's type, a female, from South Carolina, near Greenville (Dr. Cabanis), is perhaps the closely allied $C$. spinosus Bundy. I have seen types of $C$. Peale $i$ Girard in the Smithsonian Institution. They are large $C$. affinis, as Hagen suspected.

4.t. Cambarus Sloanit.

Cambarus Sloanii, Bundy, Bull. Ill. Mus. Nat. Hist., No. I. p. 24. 1876. - Proc. Acad. Nat. Sci. Phila., 1877, p. $17 \%$.

Hab. Indiana, Kentucky.

45. Cambarus propinques.

Cambarus propinquius, Girard, op. cit., p. 88. 1852.

Cambarus propinquus, Hagen, op. cit., p. 67, Pl. I. figs. 3438, Pl. III. fig. 153. 1870.

Hab. Toronto, Province of Ontario ; Montreal, Province of Quebec; New York, Indiana, Illinois, Michigan, Lake Superior, Wisconsin, Jowa.

46. Cambarus Sanbornit.

Cambarus Sanbornii, Faxon, supra, p. 128.

Hab. Smoky Creek, Carter Co., Kentucky; Oberlin, Ohio.

47. Cambarus Harrisonit.

Cambarus Harrisonii, Faxon, supra, p. 130.

Hab. Irondale, Missouri.

48. Canibarus virilis.

Cambarus virilis, Hangen, op. cit., p. 63, P1. I. figs. 23-28, Pl. II. figs. 128-132, Pl. III. fig. 155, Pl. VIII. 1870.

Cambarus debilis, Bundy, Bull. Ill. Mus. Nat. Hist., No. I. p. 24. 1876.- Trans. Wis. Acad. Sci., V. 181. 1882.-Geol. Wis., Surv. 1873-1879, I. 403. 1883 (male, form II.).

Cambarus Couesi, Streets, Bull. U. S. Geolog. Geograph. Surv. Terr., III. 803. 1877.

Cambarus virilis, Herrick, op. cit., p. 253. 1882.

Hab. Lake Winnipeg, Saskatchewan River, Red River of the North, Toronto, and Montreal (?), Dominion of Canada; Dit- 
kota, Minnesota, Wisconsin, Iowa, Nebraska, Wyoming, Kansas, Missouri, Illinois, Indiana, Tennessee, Texas, New York?

I have examined the types of all the authors cited in the above synonymy.

49. Cambarus rusticus.

Cambarus rusticus, Girard, op. cit., p. 88. 1852.

Cambarus rusticus, Hagen, op. cit., p. 71, Pl. I. figs. 80-83, Pl. III. fig. 161. 1870.

Cambarus placidus, Hagen, op. cit., p. 65, Pl. I. figs. 76-79, Pl. III. fig. 158.

Cambarus juvenilis, Hagen, op. cit., p. 66, Pl. I. figs. 29-33, Pl. III. fig. 157.

Cambarus Wisconsinensis, Bundy, Bull. Ill. Mus. Nat. Hist., No. I. p. 4. 1876. - Trans. Wis. Acad. Sci., V. 181. 1882.Geol. Wis., Surv. 1873-1879, I. 402. 1883.

Hab. Pennsylvania, Ohio, Indiana, Illinois, Kentucky, Tennessee, Lake Superior, Wisconsin, Iowa, Missouri, Texas.

Among the large amount of material before me I find so many specimens that combine characters belonging to Hagen's three species, C. rusticus, C.placidus, and $C$. juvenilis, that I am led to consider them all as varieties or forms of $C$. rusticus. A type, male, form II., of $C$. Wisconsinensis, from Racine, Wis., received from Mis Bundy, agrees pretty closely with the form C. placidus.

50. Cambarus spinosus.

Cambarus spinosus, Bundy, Proc. Acad. Nat. Sci. Phila., 1877, p. 173.

Hab. Saluda River, South Carolina; neighborhood of Rome, Georgia; Tennessee River, near border of Georgia ; Lauderdale Co., Alabama.

51. Canbarcs Putnani.

Cambarus Putnami, Faxon, supra, p. 131.

Hab. Kentucky, Tennessee, Indiana?

52. Cambarus obscurus.

Cambarus obscurus, Hagen, op. cit., p. 69, Pl. I. figs. 72-75,

Pl. III. fig. 154. 1870.

Hab. Genesee River, Rochester, New York.

53. Canbarus forceps.

Cambarus forceps, Faxon, supra, p. 133.

Hab. Lauderdale Co., Alabama; Kinoxville, Tennessee? 
54. Cambarus montezume.

Cambarus Montezumøe, Saussure, Rev. Mag. de. Zoul., $2^{\circ}$ Sér. IX.102. 1857. - Mrém. Soc. Phys. Hist. Nat. Genève, XIV. 450, Pl. III. fig. 22. 1858.

Cambarus Montezumce, var. tridens, Von Martens, op. cit., p. 130. 1872 .

Hab. Mexico.

C. Hontezume and C. Shufeldtii are small species, distinguished from all others by the presence of hooks on the third segment of the second and third pairs of legs in the male. Dr. Hagen has given me the following note on Saussure's types of C. Montezumce in Berlin: "The types are in alcohol, male, form I., and female. In the male (young) the rostrum is nearly rounded in front. Another jar contains male, form II., and female, also from Saussure, with tridentate rostrum. The second and third pairs of legs are hooked, as is stated by Saussure." The majority of the specimens which I have seen, amounting to about seventy, have the lateral spines on the rostrum (Von Martens's var. tridens); but in some these spines are very small, and in others reduced to a mere angle at the base of the acumen. Six specimens in the Museum of Comparative Zoölogy from near Parras, Cohahuila, have the section of the carapace behind the cervical groove shorter, the areola much broader. These may prove to be a distinct species. Five dry specimens in the same collection come from Mazatlan. It appears from these that the genus Crmbarus extends in Mexico to the Pacific Ocean. Other localities are the neighborhood of the city of Mexico; * Puebla ; Lake San Roque, Trapuato.

55. Cambarus Shufetdtit.

Cambartes Shufeldtii, Faxon, supra, p. 134.

Hab. Neighborhood of New Orleaus, Louisiana.

56. Astacus (Cambaroides) Japonicus.

Astacus Juponicus, De Haan, Crustacea of Siebold's Fauna Japonica, p. 164, Pl. XXXV. fig. 9. 1842.

Astacus Japonicus, Erichson, op. cito, p. 94. 1846.

Astacus Japonicus? Kessler, Bull. Soc. Impér. Nat. Moscou, XLVIII. 364. 1874.

Hab. Japan.

The three species A. Japonicus, A. Dauricus, and A. Schrenckii, from Japan and the basin of the Amoor River, widely separated

* I have seen specimens from Lake Tezcoco, which is said to be salt. 
from the rest of their family in geographical position, form a natural group of sub-generic value to which $I$ have given the name Cambaroides. In them is found a combination of characters of Astacus and Cambarus. In the general appearance of the body, with its sub-cylindrical cephalo-thorax, and in the form of the rostrum and chelipeds, these Asiatic Astacines strikingly recall the Cambari of North America, and their affinity is made more evident through the hooked thoracic legs and tooth-tipped sexual appendages of the male. The hooks are situate, in all these species, on the third segment of the second and third pairs of legs, as in Cambarus Montezuma and Cambarus Shufeldtii. In all the male examples of Cambaroides that I have seen (one A. Dauricus, three $A$. Juponicus) the first abdominal appendages are divided into two sections by a transverse suture, and furnished with short blunt teeth at the tip. I suspect the existence of two forms of the male here, as in Cambarus, for in the male specimen of A. Dauricus the hooks on the thoracic legs are strongly developed, and some of the teeth at the apex of the first abdominal appendages are brown and corneous, whilst in the three male A. Japonicus the hooks of the thoracic legs are weak, and the terminal teeth of the first abdominal appendages are smaller and not corneous. In A. Schrenckii there is a transverse tubercle behind the sternum of the penultimate thor:acic somite, much as in Astacus proper. In A. Dauricus and A. Japonicus this transverse tubercle is hollowed out behind, but still remains closely. soldered to the sternum. The first abdominal somite of the female is devoid of appendages. I have examined the branchix in $A$. Japonicus, and find them to agree in number and arrangement with those of $A$. fuviatilis, there being one pleurobranchia (on each side) upon the last thoracic somite, and one simple branchial filament on each of the three antecedent somites. The structure of the branchix and coxopoditic setre is the same as in the true Astaci.

Prof. C. O. Whitman, to whom the Museum of Comparative Zoölogy is indebted for four specimens of $A$. Japonicus, informs me that during his sojourn in Japan he could not learn of the occurrence of Crayfishes in Hondo, or Niphon, the main island of the empire, all the specimens known to him coming from the island of Yesso. Kessler's specimens came from the same locality as Whitman's, viz. Hakodadi, Yesso. In Whitman's specimens, as in those described by Kessler, the hind border of the telson 
shows no trace of the deep notch described and figured by De Haan.

57. Astacus (Cambaroides) Dauricus. Astacus Dauuricus, Pallas, Spicilegia Zoolog., Fasc. IX. p. 81. 1772.

Daun rische Krebs, Herbst, Versuch Naturgesch. Krabben u. Krebse, II. 42.1796.

Astacus leptorrhinus, Fischer, Bull. Soc. Impér. Nat. Moscou, 1X. 467, Pl. V. fig. 1. 1836. Astacus Dauricus, Erichson, op. cit., p. 94. 1846. Astacus Davuricus, Gerstfeldt, Mém. Acad. Impér. Sci. St. Pétersbourg, VIII. 292. 18559. Astacus Dauricus, Kessler, op. cit., p. 361. 1874.

Iab. Upper portion of the basin of the Amoor River.

5S. Astacus (Cambaroides) Schrenckir. Astacus Schrenckii, Kessler, op. cit., p. 363. 187 . Hab. Lower portion of the basin of the Amoor River.

59. Astacus lílamathensis.

Astacus Klamathensis, Stimpson, Proc. Bost. Soc. Nat. Hist., VI. 87. Feb., 1857.-Journ. Bost. Soc. Nat. Hist., VI. 494. April, 1857.

Astacus Klamathensis, Hagen, op. cit., p. 93, Pl. III. fig. 169. 1870 .

Hab. Oregon, Washington Terr., British Columbia (Spence Bate); from the higher regions.

I have examined the branchix of $A$. Klamathensis, A. migrescens, and A. Gambelii, of the American Astrci. In all of them the branchial formula is the same as in $A$. Auviatilis, there being three rudimentary branchia on each side of the thorax. In A. nigrescens the two anterior ones are short, but thick. They are more highly developed in $A$. Gumbelii than in any other species of Astacus examined, presenting an interesting approach in structure to the perfectly developed branchia. Each of the rudimentary branchix is much larger than in any other species, and is jointed at a short distance from the base. At the joint there are, in the intermediate pair, two short lateral filaments; in the anterior and posterior pairs, the main stem bears one filament.

60. Astacus leniusculus.

Astracus leniusculus, Dana, Crust. U. S. Explor. Exped., I. 52 t, Pl. XXXIII. fig. 1. 1852.

Astacus leniusculus, Stimpson, Journ. Bost. Soc. Nat. Mist., VI. 493. 1857 . 
Astacus leniusculus, Hagen, op. cit., p. 94 (after Dana and Stimpson).

Hab. Washington Terr. (lower part of Columbia River, Puget Sound).

One of Dana's types is in the Smithsonian Institution (No. 2019).

The type of Astacus Oreganus Randall (Journ. Acad. Nat. Sci. Phila., VIII. 138, Pl. VII., 1839), from the Columbia River, was lost or destroyed while in the hands of the artist by whom the drawing was made, and no specimen answering to the figure or description has since been found. The figure is very faulty, as pointed out by Hagen. I am inclined to think, with Hagen, that Randall's specimen belonged to the species afterwards described by Dana as $A$. leniusculus.

61. Astacus Trowbridgir.

Astacus Trowbridgii, Stimpson, Proc. Bost. Soc. Nat. Hist., VI. 87. Feb., 1857. - Journ. Bost. Soc. Nat. IIist., VI. 493. April, 1857.

Astacus Trowbridgii, Hagen, op. cit., p. 93, Pl. III. fig. 171, Pl. X. 1870 .

Hab. Columbia River, near Astoria, Oregon; streams rumning into Shoalwater Bay, Washington Terr. (J. G. Cooper).

62. Astacus nigrescens.

Astacus nigrescens, Stimpson, Proc. Bost. Soc. Nat. Hist., VI. 87. Feb., 1857. — Journ. Bost. Soc. Nat. Hist., VI. 492. April, 1857.

Astacus nigrescens, Hagen, op. cit., p. 92, Pl. III. fig. 168. 1870 .

Astacus nigrescens, Huxley, The Crayfish, p. 244, fig. 61, C, F, I, fig. 62, C, F. 1880 .

Hab. San Francisco, California; Steilacoom, Washington Terr.

63. Astacus Gambeiti.

Cambarus Gambelii, Girard, op. cit., p. 90. 1852.

Astacus Gambelii, Agassiz, Proc. Acad. Nat. Sci. Phila., VI. 375. 1853.

Astacus Gambelii, Stimpson, Journ. Bost. Soc. Nat. Hist., VI. 492. 1857.

Astacus Gambelii, Hagen, op. cit., p. 90, Pl. I. figs. 97, 98, Pl. III. fig. 170, Pl. XI. 1870.

Hab. Utah, Idaho, Montana, Wyoming? California? 
A. Gambelii has the most eastern range of any of the American Astaci. It is found in the Great Salt Lake Valley, and in the upper waters of the Snake River, Idaho. From this region it has passed over the divide into the Yellowstone Valley, and invaded the territory of the Cambari as far as the confluence of the Yellowstone and the Missouri. An examination of the physical geography of this region shows that the migration of a Western species into the Mississippi basin at this point is no difficult matter, the divide separating the waters of the Yellowstone from those of the Snake River being very low, hardly above the level of the ancient Yellowstone Lake.* In the U. S. National Museum are two young specimens, labelled, "Willow Creek, Oct. 9, 1872. Dr. Curtis." An added ticket reads, "Wyoming Terr.?" Willow Creek in Wyoming Territory flows into the South Fork of the Platte, another aftluent of the Missouri. Girard's types are said to have come from "California"; but whether this signifies California as now limited, I cannot say. In the U. S. National Museum are some specimens marked, "Found in bottle containing specimens from Santa Barbara. Dr. Webb." It is doubtful whether these were really collected at Santa Barbara. I have seen no authentic specimens from California.

64. Astacus torrentium.

Cancer torrentium (Steinkrebs), Schrank, Fauna Boica, III. 247. 1803.

Astacus torrentium (Steinkrebs), Wolf, Mag. neuesten Zustand Naturkunde (Voigt), XI. 42-45, Pl. I. figs. 1, 2. 1806.

Astacus saxatilis, Koch, Deutschlands Crust. Myriap. u. Arach., Heft 7, No. 1, with fig. (Panzer u. Herrich-Schiiffer's Deutschlands Insecten, Heft 140, No. 1). 1835.

Astacus tristis, Koch, op, cit., Heft 7 (140), No. 2, with fig. 1835.

Astacus torrentium, Koch, op. cit., Heft 36 (186), No. 24, with fig. 1841.

Astacus torrentium, Erichson, † op. cit., p. 92. 1846.

Astacus saxatilis, $\dagger$ Erichson, op. cit., p. 92.

Astacus tristis, Erichson, op. cit., p. 93.

* See IV. II. Ilolmes's Report on the Geology of the Yellowstone National Park, in 12th Ann. Rep. U. S. Geolog. Surv. of the Territories, for 1878, Part II. p. 56, 1883 .

† Erichson had an opportunity to examine Koch's types of A.torrentium, A. saxatilis, and A.tristis, and notes their clear specific separation from A. fluvi- 
Steinkrebs, Lereboullet, Comptes Rendus, XXXIII. 379. 1851.

Astacus longicomis, Lereboullet, Mém. Soc. Nat. Strasbourg, V. 2 (separate pagination), Pl. I. figs. 2-2d. 1858.

Astacus torrentium (Steinkrebs) (in part), Gerstfeldt, Mém. Acad. Impér. Sci. St. Pétershourg, IX. 574, 579, 581, 584. 1859. (after Koch, Erichson, and Lereboullet).

Astacus torrentium (Steinkrebs), Klunzinger, Jahresh. Vereins vaterlïndl. Naturkunde Württemberg, XXXVIII. 340. 1882.

Hab. Central Europe (Bohemia, Bavaria, Würtemberg, Alsace)*.

The branchial formula of $A$. torrentium is the same as that of A. pallipes.

65. Astacus pallipes.

? Astacus astacus, Pennant, Brit. Zoöl., IV. 18, Pl. XV. fig. 27. 1777.

Astacus fluviatilis (in part), Milne Edwards, op. cit., II. 330. 1837 (first "variety" noted on p. 331). - Cuvier's Règne Animal, Disciples' er., Crust., P1. XLIX. fig. 2.

Duhlenkrebs, $\uparrow$ Lereboullet, Comptes Rendus, XXXIII. 376. 1851.

Astacus flviatilis, Bell, Hist. Brit. Stalk-eyed Crust., p. 237, with cut. 1853.

Astacus pallipes, Lereboullet, Mém. Soc. Sci. Nat. Strasbourg, V. 7 (separate pagination), PI. II., Pl. III. figs. 3-3 $3^{\mathrm{d}} 1858$.

Astucus pallipes, var. flavus, Lereboullet, Mém. Soc. Sci. Nat. Strasbourg, V. 9. 1858.

Astacus torrentium (Steinkrebs) (in part), Gerstfeldt, op. cit., p. 577.1859.

Astacus saxatilis, Heller, Die Crust. südl. Europa, p. 217, Pl. VII. fig. 5. 1863.

? Astacus fontinalis (l'écrevisse ì piecls blancs), Carbonnier, L'Écrevisse, p. 8. 1869.

atilis, and their close affinity with each other. He shows that the dark color of 1. tristis is due to a coat of adlesive mould, and dismisses the question of the specific value of the differences with the remark that the distinctions may have been more evident during life.

* A. forrentium, A. pallipes, and A. fluviatilis have been so generally confounded by European authors that the data are insufficient for definitely fixing their geographical range.

$\uparrow$ Here considered by Lereboullet but a variety of $\boldsymbol{A}$. fluviutilis. 
Potamobius astacus, G. B. Sowerby, Continuation of Leach's Malacostraca Podophthalma Britannix, Nos. XVIII., XIX., Pl. XXXIV. fig. 1. 1875.

Astacus fluviatilis,* Huxley, op. cit., passim, and p. 230 in particular, frontispiece and figs. 1-60. 1880.

Astacus torrentium, * Huxley, op. cit., p. 296, fig. 61, A, D, G, fig. 62, A, D. 1880 .

Astacus pallipes (der Dohlenkrebs), Klunzinger, op. cit., p. 341. 1882.

Hab. Southern and Western Europe: Grecce, Dalmatia, Islands of Cherso and Veglia, Trieste, Italy (Heller); France; Switzerland; Alsace (Lereboullet); Spain (Huxley); England, Ireland.

66. Astacus fluviatilis.

? Cammarus, Belon, De Aquatil., p. 353, fig. on p. 355. 1553. Astacus fluviatilis, Rondelet, Univ. Aquatil. Hist., Pars II. p. 210, with cut. 1555 .

Astacus fluviatilis, Gesner, Hist. Animal., Lib. IV. p. 120, with cut. 1558 (in part: Edelkrebs, $\uparrow$ p. 122).

Cammarus, Mattioli, Comment. Dioscor. de Med. Mat., Lib. II. p. 309, with fig. 1565 .

Cammarus, seu Astacus fluviatilis, Aldrovandi, De Reliq. Animal. Exang.: Moll., etc., Cap. VI. p. 127, with cuts. 1606 (in part: Krebs, Edelkrebs, p. 129).

Cammarus, seu Astacus fluviatilis, Jonston, Hist. Nat. de Exang. Aquat., Lib. IV. p. 18, Pl. II. fig. 4, Pl. III. figs. 2, 3, 4, Pl. IV. fig. 1 (fig. 2 after Aldrovandi). 1650.

Cancer macrourus; rostro supra serrato, etc., Linne, Fauna Suecica, p. 358. 1746.

Der Fluskirebs, Rösel, Insekten-Belustigung, Th. III. p. 305, Pl. LIV. - LXI. 1755.

Cancer astacus, Linne, Syst. Nat., 10th ed., I. 631, 1758; 12th ed., I. 1051, 1767.

Astacus fluviatilis, Fabricius, Systo Entomol., p. 413. 1775.

* Huxley leaves the question of the specific or the varietal value of the forms A. nobilis and $A$. torrentium $(=A$. fuviatilis and $A$. pallipes) undecider.

$\dagger$ Under the name Astacus fluviatilis, Cammarus, or Gammarus, the older authors included not only the Edelkrebs, or the species to which the name A. fluviatilis is now restricted, but also the Steinkrebs or Thulkrebs, a smaller form now known as $A$ torrentium. Indeed, it is probable that these authors confounded $A$. torrentium and $A$. pallipes under the name Sieinkrebs. 
- Spec. Insect., I. 509. 1781.-Mantissa Insect., I. 331. 1787. - Entomol. Syst. em. et aucta, II. 478. 1793. - Supplem. Entomol. Syst., p. 406. 1798.

Astacus fluviatilis, De Geer, Mém. Hist. Ins., VII., Pl. XX.XXII. 1778.

Cancer astacus, Herbst, op. cit., II. 38, Pl. XXIII. fig. 9. 1796 (in part: Edle Krebse, p. 41).

Astacus fluviatilis, Latreille, Hist. Nat. Crust. et Ins., I. 367, Pl. III. 1801; III. 33, 1801; V. 235, 1802.

Astacus fluviatilis, Bosc, Hist. Nat. Crust., II. 62, Pl. XI. fig. 2. 1802 .

Cancer nobilis (Edelkrebs), Schrank, op. cit., p. 246. 1803. Edelkrebs, Wolf, op. cit., Pl. I. fig. 3. 1806.

Astacus fluviatilis, Brandt and Ratzeburg, Mred. Zoöl., II. 58, Pl. X., XI. 1833.

Astacus fluviatilis (in part), Milne Edwards, op. cit., II. 330. 1837 (second "variety" noted on p. 331).

Astacus fuviatilis, Koch, op. cit., Heft 36 (186), No. 23, with fig. 1841 .

Astacus fluviatilis, Erichson, op. cit., p. 90. 1846.

Astacus fluviatilis, Lereboullet, op. cit., V., PI. III. figs. 1-1 $1^{\mathrm{d}}$. 1858.

Astacus fluviatilis communis, Gerstfeldt, op. cit., pp. 554, 584. 1855 .

Astacus fuviatilis, Heller, op. cit., p. 214, Pl. VII. figs. 3, 4. 1863.

Astacus fluviatilis (l'écrevisse à pieds rouges), Carbonnier, op. cit., p. 8. 1869.

Astacus fluviatilis, Kessler, op. cit., p. 257. 1874.

Astacus nobilis, * Huxley, op. cit., pp. 295, 296, fig. 61, B, E, H, fig. 62, B, E. 1880.

Astacus fluviatilis (Edelkrebs), Klunzinger, op. cit., XXXVIII. 342. 1882.

Hab. Russia (Baltic water-shed and small streams of the upper part of the basin of the Dnieper), Austria, Germany, France, Italy? It is also found in Denmark according to Huxley, and in the Scandinavian peninsula. It appears to have been artificially introduced into the latter. It was scarcely known in Sweden before the time of John III. (1568-1592). $\dagger$ From Sweden

* See first foot-note on preceding page. $†$ Linne, Fauna Suecica, p. 358, 1746. 
it has spread into Southeastern Norway.* The Astaci of Spain are probably all $A$. pallipes, as well as those of England and Ireland.

67. Astacus leptodactrlus.

Astacus leptodactylus, Eschscholtz, Mém. Soc. Impér. Nat. Moscou, VI. 109, Pl. XVIII. 1823.

Astacus leptodactylus, Rathke, Mém. Acad. Impér. Sci. St. Pétersbourg, III. 359, Pl. IV. figs. 1, 2. 1837 (separate, 1836). Astacus leptodactylus, var. Caspia, Eichwald, Bull. Soc. Impér. Nat. Moscou, 1838, p. 148. - Fauna Caspio-Caucasia, p. 179, Pl. XXXVI. fig. 1. 1841.

Astacus leptodactylus, var. salinus, Nordmann, Obs. sur la Faune Pontique, in Demidoff's Voy. dans la Russ. Mérid. et la Crimée, Atlas, Crust., Pl. I. (No date.†)

Astacus leptodactylus, Erichson, op. cit., p. 90. 1846.

Astacus fluviatilis, var. leptodactylus, Gerstfeldt, op. cit., pp. 558, 584. 1859 .

Astacus leptodactylus, Heller, op. cit., p. 215, Pl. VII. fig. 6. 1863.

Astacus leptodactylus, Kessler, op. cit., p. 249. 1874.

Hab. Russia (rivers of the Ponto-Caspian basin on the north from the Danube to the Ural Mountains and the Muchojar Iills in Western Siberia, rivers and lakes draining into the Baltic and White Sea), Caspian Sea, Austria (basin of the Danube). Artificially introduced into affluents of the Tobol River, a tributary of the Irtish, Siberia, $\ddagger$ where it has rapidly multiplied.

a. Var. angulosa.

Astacus angulosus, Rathke, op. cit., p. 364, Pl. IV. fig. 3. 1836. Astacus angulosus, Erichson, op. cit., p. 91.1846 (after Rathke).

Astacus fluviatilis, var. angulosus, Gerstfeldt, op. cit., pp. 563, 584. 1859.

Astacus angulosus, Heller, op. cit., p. 216. 1863.

Astacus leptodactylus, var. angulosus, Kessler, op. cit., p. 251. 1874.

Hab. Crimea and adjacent region.

* G. O. Sars, Hist. Nat. Crust. d'Eau Douce de Norvège, p. 11, 1867.

$\dagger$ The text is dated 1840 .

$\ddagger$ Middendorf, Sibirische Reise, IV., Th. 2, p. 885, 1867. Kiessler, op. cit., p. 371 . 
There has lately appeared an insufficient preliminary notice, by Wladimir Schimkewitsch, ${ }^{*}$ of an Astacus from the neighborhood of the town of Toorkistan in the valley of the Jaxartes. It is closely related to $A$. fluviatilis and A. leptodactylus, perhaps not specifically distinct from one of these. Schimkewitsch affirms that intermediate forms connect $A$. pachypus with A.leptodactylus (Government of Riazan) and A. leptodactylus with $A$. fluviatilis (Governments of Toola and Moscow).

68. Astacus PaChypus.

Astacus pachypus, Rathke, op. cit., p. 365. 1836.

Astacus Caspius, Eichrvald, Bull. Soc. Impér. Nat. Moscou, 1838, p. 149. - Fauna Caspio-Caucasia, p. 181, Pl. XXXVI. fig. 2. 1841 .

Astacus pachypus, Erichson, op. cit., p. 91. 1846 (after Rathke).

Astacus Caspinis, Erichson, op. cit., p. 92 (after Eichwald).

Astacus fluviatilis, var. pachypus et Caspius, Gerstfeldt, op. cit., pp. 566, 584. 1859 .

Astacus pachypus, Heller, op. cit., p. 217. 1863.

Astacus pachypus, Kessler, op. cit., p. 254. 1874.

Hab. Brackish waters of the Caspian Sea and estuaries of rivers flowing into the Caspian and Black Seas.

69. Astacus Colchicus.

Astacus Colchicus, Kessler, Bull. Soc. Impér. Nat. Moscou, L. 2. 1876 .

Hab. Upper portion of Rion River and tributaries, Asiatic Russia. It has been artificially introduced into some of the tributaries of the Upper Koor (anc. Cyrus). (Kessler.)

* Der turkestanische Flusskrebs. (Vorläufige Mittheilung.) Von Wladimir Schimkewitsch. Zoologischer Anzeiger, VII. 339, 23 Juni, 1884. 

Larer 






